\section{$\$$ Research Square}

\title{
Quantitative Proteomic Analysis Shows Involvement of the p38 MAPK Pathway in Bovine Parainfluenza Virus type 3 Replication
}

\section{Liyang Li}

Heilongjiang Bayi Agricultural University https://orcid.org/0000-0002-4633-9419

\section{Pengfei Li}

The Fifth Affiliated Hospital of Harbin Medical University

\section{Ao Chen}

Heilongjiang Bayi Nongken University: Heilongjiang Bayi Agricultural University

Hanbing Li

Heilongjiang Bayi Agricultural University

\section{Zhe Liu}

Heilongjiang Bayi Agricultural University

\section{Liyun Yu}

Heilongjiang Bayi Agricultural University

Xilin Hou ( $\sim$ houxilin@byau.edu.cn )

\section{Research}

Keywords: Bovine parainfluenza virus type 3 (BPIV3), Differentially expressed proteins, p38 MAPK signaling pathway, Quantitative proteomics

Posted Date: August 23rd, 2021

DOI: https://doi.org/10.21203/rs.3.rs-253558/v2

License: (c) (i) This work is licensed under a Creative Commons Attribution 4.0 International License.

Read Full License 


\section{Quantitative proteomic analysis shows involvement of the p38}

\section{MAPK pathway in bovine parainfluenza virus type 3 replication}

Liyang $\mathrm{Li}^{\mathrm{a}}{ }^{\mathrm{a}, \mathrm{b}, 1}$, Pengfei $\mathrm{Li}^{\mathrm{c}, 1}$, Ao Chen ${ }^{\mathrm{a}}$, Hanbing $\mathrm{Li}^{\mathrm{a}}$, Zhe $\mathrm{Liu}^{\mathrm{a}}$, Liyun $\mathrm{Yu}^{\mathrm{a}}{ }^{*}$, Xilin Hou ${ }^{\mathrm{b}}$

a College of Life Science and Biotechnology, Heilongjiang Bayi Agricultural University, Daqing 163319, China

b College of Animal Science and Veterinary Medicine, Heilongjiang Bayi Agricultural University, Daqing 163319, China

c Department of Nephrology, The Fifth Affiliated Hospital of Harbin Medical University, Daqing 163319, China

1 These authors equally contributed to this work.

* Corresponding author. Tel.: +86 04596819291 ; fax: +86 04596819291.

E-mail address: houxilin@byau.edu.cn; yuliyun1227@126.com 


\begin{abstract}
Background: Bovine parainfluenza virus type 3 (BPIV3) infection often causes respiratory tissue damage and immunosuppression and results in bovine respiratory disease complex. Bovine respiratory disease complex is one of the major diseases in dairy cattle and causes huge economical losses every year. The pathogenetic and immunoregulatory mechanisms involved in the process of BPIV3 infection, however, remain unknown. Proteomics is a powerful tool for high-throughput identification of proteins and has been widely used to understand how viruses interact with host cells. Methods: In the present study, we report a proteomic analysis to investigate the whole cellular protein alterations of MDBK cells infected with BPIV3. To investigate the infection process of BPIV3 and the immune response mechanism of MDBK cells, isobaric tags for relative and absolute quantitation analysis (iTRAQ) and Q-Exactive mass spectrometry-based proteomics were performed. The differentially expressed proteins (DEPs) involved in the BPIV3 invasion process in MDBK cells were identified, annotated, and quantitated. Results: A total of 116 proteins, which included 74 upregulated proteins and 42 downregulated proteins, were identified as DEPs between the BPIV3-infected and the mock-infected groups. These DEPs included corresponding proteins related to inflammatory response, immune response, and lipid metabolism. These results might provide some insights for understanding the pathogenesis of BPIV3. Fluorescent quantitative PCR and western blotting analysis showed results consistent with those of iTRAQ identification. Interestingly, the upregulated protein MKK3 was associated with the p38 MAPK signaling pathway. Conclusions: The results of proteomics analysis indicated BPIV3 infection could activate the p38 MAPK pathway to promote virus replication.
\end{abstract}

Keywords: Bovine parainfluenza virus type 3 (BPIV3); Differentially expressed proteins; p38 MAPK signaling pathway; Quantitative proteomics 


\section{Introduction}

Bovine parainfluenza virus type 3 (BPIV3) is an enveloped, single-stranded negative-sense RNA virus that belongs to the family Paramyxoviridae, genus Respirovirus[1]. BPIV3 infection results in pneumonia and atypical interstitial pneumonia in cattle and leads to severe secondary bacterial infection and other related clinical symptoms. BPIV3 infection and other viral or bacterial infections often cause bovine respiratory disease complex (BRDC)[2]. The mortality of cattle due to BRDC is up to $35 \%$, which causes huge economic losses in the cattle industry [3]. The genome of BPIV3 contains a single-stranded negative-sense RNA of approximately $15 \mathrm{~kb}$ in size and encodes six structural proteins and three nonstructural proteins $[4,5]$. The structural proteins of BPIV3 include nucleoprotein $(\mathrm{N})$, phosphoprotein $(\mathrm{P})$, large protein $(\mathrm{L})$, matrix protein (M), hemagglutinin-neuraminidase (HN), and the homotrimeric fusion (F), while the accessory nonstructural proteins include $\mathrm{C}, \mathrm{V}$, and $\mathrm{D}$ proteins. Multiple functions and activities of the structural and accessory proteins have been investigated. For example, the glycoprotein HN binds to the receptor protein on the host cell surface, followed by the fusion protein $F$ to induce membrane fusion $[6,7]$. The conserved, nonglycosolated matrix protein(M), is the most abundant viral protein in an infected cell. The nonstructural proteins including $\mathrm{V}$ protein and $\mathrm{C}$ protein are also encoded by the $\mathrm{P}$ gene. The $\mathrm{V}, \mathrm{C}$, and $\mathrm{N}$ proteins together regulate virus replication [5]. Although much progress has been made in understanding the proteins of BPIV3, the pathogenetic and immunoregulatory mechanisms involved in the process of BPIV3 infection remain largely unclear. To investigate the changes in the host physiological system during the process of viral invasion, isobaric tags for relative and absolute quantitation analysis (iTRAQ) mass spectrometry (MS)-based global proteomics profiling was performed.

The iTRAQ quantitative proteomics technique has been widely used to study interaction between virus and host based on high sensitivity and quantitation accuracy[8, 9]. An et al. used iTRAQ to determine the differentially expressed proteins (DEPs) of transmissible gastroenteritis virus (TGEV)-infected PK-15 cells. The authors identified 60 upregulated and 102 downregulated proteins in the TGEV infection process. Their analysis revealed that many upregulated proteins were associated with interferon signaling and that TGEV infection could activate the JAK-STAT1 signaling pathway [10]. Sun et al. used the iTRAQ quantitative proteomics technique to identify proteins associated with porcine epidemic diarrhea virus (PEDV) infection in order to provide a scientific basis for the pathogenesis of PEDV [11]. Presently, iTRAQ had become the main quantitative proteomics technology to understand the process of viral infection. In the present study, the DEPs in BPIV3-infected MDBK cells were identified and quantitatively analyzed by using an iTRAQ-based proteomics approach. MDBK cells have been selected for use in many studies $[12,13]$. MDBK cells are commonly used not only for BPIV3 isolation, propagation and basic research, but also as hosts for many different bovine pathogens, including bovine respiratory syncytial virus (BRSV) and bovine herpesvirus type $1[14,15]$.

The expression levels of 116 proteins were found to be significantly altered after $24 \mathrm{~h}$ of 
BPIV3 infection. These cellular DEPs were assigned to several biological processes according to bioinformatics analysis. The results of this study provide a global understanding of the host's immune response to BPIV3 infection.

\section{Materials and methods}

\section{Virus infection of MDBK cells}

MDBK cells were cultured in DMEM (Dulbecco's modified Eagle's medium) medium containing $10 \%$ fetal bovine serum (FBS) and $100 \mathrm{~g} / \mathrm{ml}$ penicillin and $100 \mathrm{~g} / \mathrm{ml}$ streptomycin. Cell culture conditions at $37{ }^{\circ} \mathrm{C}$ with $5 \% \mathrm{CO}_{2}$ in $24 \mathrm{~h}$. The BPIV3 DQ strain (GenBank accession no. HQ462571) was isolated and identified in the preventive veterinary laboratory of Heilongjiang Bayi Agricultural University. MDBK cells were transduction with BPIV3 at multiplicity of infection $(\mathrm{MOI}=1)$. Uninfected cells were used as mock-infected groups. Each experiment were carried out with three replicates. The cytopathic effect (CPE) was observed and the growth curve of BPIV3 was measured. TCID 50 were measured by the Reed-Muench method.

\section{Protein isolation, digestion, and labeling with iTRAQ reagents}

All the cells samples, included BPIV3-infected group and control group, were cleaned with cold PBS twice and centrifuged at $1000 \mathrm{~g}$ at $4{ }^{\circ} \mathrm{C}$ for 10 minutes to harvested cells. Then, the collected cells were lysed to extract proteins in the $300 \mu \mathrm{LDT}$ ( $1 \mathrm{mM}$ PMSF, $2 \mathrm{mM}$ EDTA and 10 $\mathrm{mM}$ DTT). Protein samples of dissolved were harvested with centrifugation at $14000 \mathrm{~g}$ for $40 \mathrm{~min}$ at $4{ }^{\circ} \mathrm{C}$. The concentration of harvested protein supernatant was determined using BCA protein assay. Results showed that $100 \mu \mathrm{g}$ protein was digested for $8 \mathrm{~h}$ at $37^{\circ} \mathrm{C}$ using sequencing-grade modified trypsin. The protein samples were labeled by different iTRAQ tags on the basis of iTRAQ Reagent-8plex Multiplex Kit instruction (AB SCIEX). Three mock-infected samples were labeled by iTRAQ 113, iTRAQ 114, and iTRAQ 115, respectively; three BPIV3-infected samples were labeled by iTRAQ 116, iTRAQ 117 and iTRAQ 118, respectively. Then the labeled samples were mixed and dried by using vacuum concentrator.

\section{LC-MS/MS Analysis}

The labeled peptide samples were purified and separated by AKTA purification system. The operation methods and solution preparation were performed essentially as described previously [16]. The whole elution process was monitored at $214 \mathrm{~nm}$ and collected every minute. Thirty distillates were collected and neutralized in 10 pools and desalinated in a 18 cartridge. After each fraction was vacuum centrifuged, the sample was dissolved in $40 \mu \mathrm{L} 0.1 \%$ trifluoroacetic acid and kept frozen at $-80{ }^{\circ} \mathrm{C}$ for mass spectrometry analysis. Each sample was separated by capillary high-performance liquid chromatography (Thermo scientific EASY column $(2 \mathrm{~cm}, 100 \mu \mathrm{m} 5 \mu \mathrm{m}$, C18). The chromatography conditions were as follow: Water with $0.1 \%$ formic acid (A) and Acetonitirile with $0.1 \%$ formic acid (B) were used as mobile phage. The flow rate was $300 \mathrm{~nL}$ per 
minute and the mobile phage gradient program was used: $0-33$ minute, from $0 \%$ to $40 \%$ (B); 33-34 minute, B from $40 \%$ to $100 \%$ (B); $34-35$ minute maintained $100 \%$ and then back to $40 \%$. Then, proteins were analyzed by using a Q-Exactive mass spectrometry (Thermo Finnigan) at positive ion mode (parameters: mass range: $300-1800 \mathrm{~m} / \mathrm{z}$; Dynamic exclusion: $40.0 \mathrm{~s}$, MS2 Activation Type: HCD, Normalized collision energy: $30 \mathrm{eV}$ ).

\section{Database search and bioinformatic analysis}

MS/MS data were searched against the bovine subset database from the UniProt database (release March 22, 2016, containing 32015 sequences) and proteins were identified by using Mascot 2.3.02. The peptide for quantification was automatically selected by Paragon ${ }^{\mathrm{TM}}$ algorithm to calculate the reporter peak area, error factor $(\mathrm{EF})$ and $\mathrm{p}$-value. The proteins expression levels of BPIV3-infected cells were calculated to compare with those of mock-infected cells. Proteins with fold changes $>1.5$ and p-values $<0.05$ were considered as significantly different expressions. Auto bias-corrected were executed to decrease artificial error. These proteins were further classified using Gene Ontology (GO) and pathway enrichment analysis (http://www.geneontology.org).

\section{RNA extraction and real-time PCR analysis}

The mRNA level of differentially expressed proteins was analyzed by real-time PCR. Total RNA was extracted from cells of the BPIV3 infected group and the control group using TRIzol reagent (Takara) according to the manufacturer's protocol. The RNA concentration was measured using NanoDropnd-1000. After extraced, $1 \mu \mathrm{L}$ total RNA was detected using electrophoresis. The cDNAs of these samples were obtained by reverse transcription. Relative quantitative real-time PCR was performed in a $25 \mu \mathrm{L}$ system that containing $12.5 \mu \mathrm{L}$ SYBR Premix Ex TaqTM II, $2 \mu \mathrm{L}$ primers, $2 \mu \mathrm{L}$ cDNA samples and $8.5 \mu \mathrm{L}$ water. The reaction condition was $95{ }^{\circ} \mathrm{C}$ for $10 \mathrm{~min}$, then 40 cycles of $95{ }^{\circ} \mathrm{C}$ for $30 \mathrm{~s}, 57^{\circ} \mathrm{C}$ for $30 \mathrm{~s}$ and $72{ }^{\circ} \mathrm{C}$ for $30 \mathrm{~s}$, Then, the melting curves were obtained. The gene of GADPH was used as the internal reference gene. The data statistic was based on three independent experiments.

Table 1 The primers of genes $\left(5^{\prime} \rightarrow 3^{\prime}\right)$

\begin{tabular}{|c|c|c|c|c|}
\hline Gene name & Acc. Number & Primer & Sequence & length \\
\hline \multirow[t]{2}{*}{ MHC II } & Q9TTM7 & FwdRev & GAGCGAGTGTCATTTCTTCAAC & 22 \\
\hline & & Fwd & GCACGAACTCTTCTCCATTATG & 22 \\
\hline \multirow[t]{2}{*}{ GSTA1 } & A5PJE0 & Rev & TCCAAGAGAGGGCAACAAAC & 20 \\
\hline & & Fwd & TCCACATAATAGAGCAATTCAACC & 24 \\
\hline \multirow[t]{2}{*}{$M K K 3$} & A4IFH7 & Rev & TGAAGCAGGTGGTAGAGGAG & 20 \\
\hline & & Fwd & CACGAAGGCAGCGATGTC & 18 \\
\hline \multirow[t]{2}{*}{$A P-2$} & P63009 & Rev & GTGATTGCTGCTATGACTGTG & 21 \\
\hline & & Fwd & ATGTCTGGCTGACTCTTGG & 19 \\
\hline \multirow[t]{2}{*}{ MARCS } & P12624 & Rev & CTACAGTGCGGCTACAAATC & 20 \\
\hline & & Fwd & TGAAGAGGACAGAACAGAACC & 21 \\
\hline
\end{tabular}




\begin{tabular}{cccll}
\hline Sep & P49907 & Rev & GCTGGCTCTGGCTCTCTG & 18 \\
& & Fwd & GGTGGAGGTTGCTTACAATAGG & 22 \\
FGF13 & BC149415 & Rev & GCTGAACGGAGGCAAGTC & 18 \\
& & Fwd & TGATGGCAGATTAGAATAGTGAAC & 24 \\
\multirow{2}{*}{ TFPI } & Q7YRQ8 & Rev & GGCTGTGTTCTGCTAATGTC & 20 \\
& & Fwd & AGTCTTGGCATCTTCTTGTTC & 21 \\
GADPH & AB098979 & Rev & TTCAACGGCACAGTCAAGG & 19 \\
& & & CTCAGCACCAGCATCACC & 18 \\
\hline
\end{tabular}

\section{Western-blot}

MDBK cells were washed two times with PBS and disrupted with lysis buffer $(50 \mathrm{mM}$ Tris- $\mathrm{HCl}, \mathrm{pH} 8.0,150 \mathrm{mM} \mathrm{NaCl}$ and $1 \%$ Triton $\mathrm{X}-100$, supplemented with 1 tablet of Complete-Mini Protease Inhibitor Cocktail per $50 \mathrm{ml}$ buffer). Cell lysates were centrifugated at $12,000 \times \mathrm{g}$ for $10 \mathrm{~min}$ to harvest supernatants. Protein assays were performed on all supernatants using the Bradford method. For Western blot analysis of whole-cell lysates, samples, each containing 25-30 $\mu \mathrm{g}$ of protein equivalent, were dissociated in SDS-PAGE loading buffer and separated by $12 \%$ gradient SDS-PAGE. Proteins were then transferred to a nitrocellulose membrane. After sample separation by electrophoresis, proteins were transferred to an Immobilon-FL membrane (Millipore) via electroblotting. Primary anti-bodies and dilutions including MKK3 (rabbit, Cell Signal Technology5674, Danvers, MA), p38 phosphorylation (p-38) at 1:1000 (mouse, Cell Signal Technology9216, Danvers, MA ), p-38 at 1:1000 (rabbit, Cell Signal Technology41666, Danvers, MA), $\beta$-actin at 1:10,000 (mouse, Sigma) and were incubated with membrane at $4{ }^{\circ} \mathrm{C}$ over-night. As a secondary antibody, anti rabbit immunoglobulin G (Santa Cruz Biotechnology Inc.) was applied (1:1000, rabbit or mouse) at room temperature for $1 \mathrm{~h}$. After further washes, the immune complexes were revealed by enhanced chemluminescence using the ECL detection kit (Beijing Biosea Biotechnology Co., Ltd.).

\section{Indirect immunofluorescent assay (IFA)}

The operation methods were performed essentially as described previously [12]. MDBK cells were fixed with $4 \%$ paraformaldehyde for 10 min, permeabilized with $0.1 \%$ Trinton X-100 for 20 min, blocked with $1 \%$ BSA for $2 \mathrm{~h}$, and washed with PBS three times. Cells were incubated with $200 \mu \mathrm{L}$ rabbit polyclonal anti-BPIV3 serum (1:100) for $1 \mathrm{~h}$, followed by incubation with $200 \mu \mathrm{L}$ FITC-conjugated Goat anti-rabbit $\operatorname{IgG}(1: 100)$ for $1 \mathrm{~h}$ at room temperature. The cells were washed extensively with PBS, and $90 \%$ glycerol was added to mount cells. Cells were examined and images were captured using fluorescence microscope.

\section{Statistical analysis}

Statistical analysis was performed in Microsoft Excel for two-tailed Student's $t$ test or 
one-way analysis of variance (ANOVA) and the p-values $<0.05$ were considered statistically significant.

\section{Results}

\section{Detection of the activity of BPIV3 in MDBK cells}

In proteomics analysis of virus-infected cells, the optimal sampling time is when the virus replicates quickly and the cells have no significant pathological effect (CPE). To determine the optimal sampling time point for proteomics analysis after BPIV3 infection, MDBK cells were cultured in a monolayer and inoculated with BPIV3. At different time points after inoculation, the cell-virus suspension was harvested at $6,12,18,24,36,48$, and $60 \mathrm{~h}$, and $\operatorname{TCID}_{50}$ was measured. The growth curve of BPIV3 was plotted according to the results of TCID 50 . The results showed that BPIV3 proliferated rapidly from 24 to $36 \mathrm{~h}$ after infection, indicating active intracellular replication of the virus.

Because CPE is caused by intercellular fusion after BPIV3 invades the target cells, MDBK cells were inoculated with BPIV3 at the dose of 1 multiplicity of infection (MOI), and CPE was observed at different time points after infection. The results showed that lesions began to appear $12 \mathrm{~h}$ after BPIV3 infected the cells, and the lesions became more apparent with time (Fig. 1). The viral titer reached a plateau of approximately $5.7 \log 10$ at 36 hpi and then gradually and continuously declined. Generally, the time point at which viral replication remains high but no signifificant host cell cytoskeleton or membrane rearrangement is observed is the optimal time for a proteomic analysis[12]. According to the post-infection cytopathic conditions combined with virus proliferation, cells infected at $24 \mathrm{~h}$ were used as the time point for proteomics analysis.

\section{Protein profiling and iTRAQ quantification}

The collected protein samples of BPIV3-infected and mock-infected MDBK cells were labeled with iTRAQ reagent in three biological repetitions. The quantitative information of the two experimental group ratios (ratio [infection/control]) was obtained by integrating the peptide segment information of three biological duplicates in the mock-infected group (control) and the BPIV3-infected group (infection).

The changes in the protein expression level between the two groups were analyzed based on statistical significance. A total of 2804 proteins were detected and quantified by LC-MS/MS. Among these proteins, 74 proteins were significantly upregulated and 42 proteins were markedly downregulated according to the change ratio of $\geq 1.5$ for the proteins and significant differences at $P<0.05$ (Fig. 2). The most significantly upregulated protein among the DEPs was vesicle-related membrane protein, which is related to autophagy. The most significantly downregulated protein was the integrin complement protein, which is a receptor protein of viral infection(Table.2). 
Table2. The DEPs lists betweenBPIV3-infected group and mock group

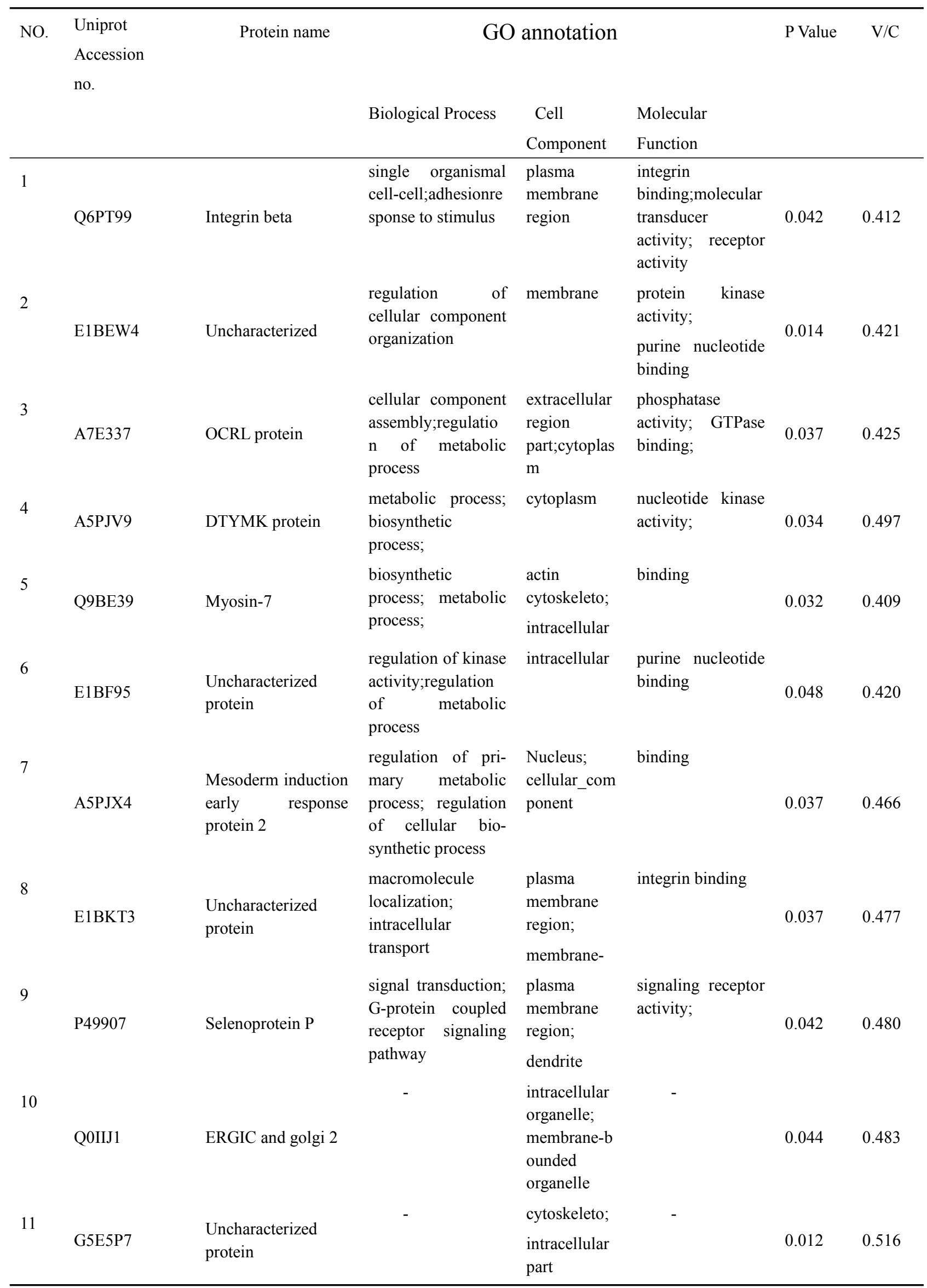




\begin{tabular}{|c|c|c|c|c|c|c|c|}
\hline 12 & G3MZ53 & $\begin{array}{l}\mathrm{N} \text {-acylglucosamine } \\
\text { 2-epimerase }\end{array}$ & $\begin{array}{l}\text { small molecule } \\
\text { metabolic process }\end{array}$ & - & $\begin{array}{l}\text { racemase and } \\
\text { epimerase activity }\end{array}$ & 0.006 & 0.524 \\
\hline 13 & F1N152 & $\begin{array}{l}\text { Serine protease } \\
\text { HTRA1 }\end{array}$ & $\begin{array}{l}\text { regulation of } \\
\text { metabolic process; } \\
\text { signal transduction }\end{array}$ & $\begin{array}{l}\text { Cytoplasm; } \\
\text { extracellular } \\
\text { matrix }\end{array}$ & $\begin{array}{l}\text { serine hydrolase } \\
\text { activity; insulin- } \\
\text { like growth factor } \\
\text { binding }\end{array}$ & 0.002 & 0.527 \\
\hline 14 & Q3T0D7 & $\begin{array}{l}\text { GTP-binding } \\
\text { protein SAR1a }\end{array}$ & $\begin{array}{l}\text { macromolecule } \\
\text { localization; } \\
\text { cellular component } \\
\text { assembly }\end{array}$ & $\begin{array}{l}\text { endoplasmic } \\
\text { reticulum; } \\
\text { membrane-b } \\
\text { ounded } \\
\text { vesicle }\end{array}$ & $\begin{array}{l}\text { small molecule } \\
\text { binding; }\end{array}$ & 0.049 & 0.528 \\
\hline 15 & F1MDD5 & $\begin{array}{l}\text { Uncharacterized } \\
\text { protein }\end{array}$ & $\begin{array}{l}\text { developmental } \\
\text { process;cell } \\
\text { differentiation }\end{array}$ & $\begin{array}{l}\text { extracellular } \\
\text { organelle }\end{array}$ & receptor binding & 0.007 & 0.529 \\
\hline 16 & F1MWI1 & Clusterin & $\begin{array}{l}\text { cell death;cellular } \\
\text { process }\end{array}$ & - & - & 0.002 & 0.533 \\
\hline 17 & O18973 & $\begin{array}{l}\text { Rab5 GDP/GTP ex- } \\
\text { change factor }\end{array}$ & $\begin{array}{l}\text { regulation of } \\
\text { metabolic process; } \\
\text { regulation of } \\
\text { transport }\end{array}$ & $\begin{array}{l}\text { Cytoplasm; } \\
\text { recycling } \\
\text { endosome }\end{array}$ & $\begin{array}{l}\text { regulation of } \\
\text { metabolic process }\end{array}$ & 0.022 & 0.541 \\
\hline 18 & Q0VCC0 & Calcyphosin & $\begin{array}{l}\text { Metabolic process; } \\
\text { regulation of } \\
\text { cellular catabolic } \\
\text { proces }\end{array}$ & $\begin{array}{l}\text { cellular_com } \\
\text { ponent; } \\
\text { intracellular } \\
\text { part }\end{array}$ & cation binding & 0.001 & 0.558 \\
\hline 19 & F1MS35 & $\begin{array}{l}\text { Uncharacterized } \\
\text { protein }\end{array}$ & $\begin{array}{l}\text { cellular component } \\
\text { assembly;positive } \\
\text { regulation of } \\
\text { metabolic process }\end{array}$ & $\begin{array}{l}\text { cytoplasmic } \\
\text { vesicle; } \\
\text { nucleus }\end{array}$ & $\begin{array}{l}\text { cation } \\
\text { binding;enzyme } \\
\text { regulator activity }\end{array}$ & 0.010 & 0.560 \\
\hline 20 & Q7YRQ8 & $\begin{array}{l}\text { Tissue factor } \\
\text { pathway inhibitor } 2\end{array}$ & $\begin{array}{l}\text { regulation of } \\
\text { metabolic process; } \\
\text { circulatory system } \\
\text { development }\end{array}$ & $\begin{array}{l}\text { membrane-b } \\
\text { ounded } \\
\text { organelle; }\end{array}$ & $\begin{array}{l}\text { endopeptidase } \\
\text { regulator activity }\end{array}$ & 0.000 & 0.563 \\
\hline 21 & Q32LB6 & $\begin{array}{l}\text { TATA box-binding } \\
\text { protein-associated } \\
\text { factor RNA } \\
\text { polymerase I } \\
\text { subunit D }\end{array}$ & $\begin{array}{l}\text { regulation of } \\
\text { metabolic process }\end{array}$ & $\begin{array}{l}\text { membrane-b } \\
\text { ounded } \\
\text { organelle }\end{array}$ & $\begin{array}{l}\text { nucleic acid } \\
\text { binding }\end{array}$ & 0.031 & 0.566 \\
\hline 22 & E1BDC9 & $\begin{array}{l}\text { Uncharacterized } \\
\text { protein }\end{array}$ & $\begin{array}{l}\text { digestive tract } \\
\text { development; } \\
\text { cell differentiation }\end{array}$ & $\begin{array}{l}\text { cytoplasm; } \\
\text { endomembra } \\
\text { ne system }\end{array}$ & binding & 0.032 & 0.570 \\
\hline 23 & $\mathrm{~F} 1 \mathrm{~N} 2 \mathrm{~K} 8$ & $\begin{array}{l}\text { Uncharacterized } \\
\text { protein }\end{array}$ & $\begin{array}{l}\text { single-organism } \\
\text { developmental } \\
\text { process }\end{array}$ & $\begin{array}{l}\text { cytoplasmic } \\
\text { part }\end{array}$ & protein binding & 0.007 & 0.578 \\
\hline 24 & F1MH50 & $\begin{array}{l}\text { Uncharacterized } \\
\text { protein }\end{array}$ & $\begin{array}{l}\text { regulation of } \\
\text { cytoskeleton } \\
\text { organizatio }\end{array}$ & cytoplasm & protein binding & 0.001 & 0.579 \\
\hline 25 & G3N1L7 & $\begin{array}{l}\text { Uncharacterized } \\
\text { protein }\end{array}$ & & $\begin{array}{l}\text { extracellular } \\
\text { matrix }\end{array}$ & ion binding & 0.004 & 0.582 \\
\hline 26 & Q9TTM7 & $\begin{array}{l}\text { MHC(BoLA) class } \\
\text { II DR-beta chain }\end{array}$ & $\begin{array}{l}\text { antigen processing } \\
\text { and presentation }\end{array}$ & $\begin{array}{l}\text { extracellular } \\
\text { matrix;cytop } \\
\text { lasmic part }\end{array}$ & binding & 0.033 & 0.582 \\
\hline
\end{tabular}




\begin{tabular}{|c|c|c|c|c|c|c|c|}
\hline 27 & Q3ZC25 & $\begin{array}{l}\text { Transmembrane } \\
\text { protein 106B }\end{array}$ & $\begin{array}{l}\text { developmental } \\
\text { process; } \\
\text { cell morpho- } \\
\text { genesis }\end{array}$ & $\begin{array}{l}\text { Membrane; } \\
\text { cytoplasm }\end{array}$ & - & 0.002 & 0.582 \\
\hline 28 & E1BM92 & $\begin{array}{l}\text { Uncharacterized } \\
\text { protein }\end{array}$ & $\begin{array}{l}\text { single- } \\
\text { multicellular } \\
\text { organism process }\end{array}$ & $\begin{array}{l}\text { plasma } \\
\text { membrane } \\
\text { region; } \\
\text { cytoplasm }\end{array}$ & $\begin{array}{l}\text { cytoskeletal } \\
\text { protein binding }\end{array}$ & 0.041 & 0.588 \\
\hline 29 & Q2KI45 & $\begin{array}{l}\text { Mitochondrial } \\
\text { ribonuclease P } \\
\text { protein } 1\end{array}$ & $\begin{array}{l}\text { nucleic acid } \\
\text { metabolic process }\end{array}$ & $\begin{array}{l}\text { intracellular } \\
\text { organelle; } \\
\text { nucleoplasm }\end{array}$ & $\begin{array}{l}\text { catalytic activity; } \\
\text { transferase } \\
\text { activity }\end{array}$ & 0.033 & 0.594 \\
\hline 30 & M5FKH8 & Periplakin & $\begin{array}{l}\text { developmental } \\
\text { process; }\end{array}$ & $\begin{array}{l}\text { cytoskeleton } \\
\text {;intracellular } \\
\text { part }\end{array}$ & binding & 0.004 & 0.595 \\
\hline 31 & Q0P5F2 & $\begin{array}{l}\text { Proteasome } \\
\text { assembly chaperone } \\
1\end{array}$ & $\begin{array}{l}\text { cellular component } \\
\text { assembly; } \\
\text { organ development }\end{array}$ & $\begin{array}{l}\text { cytoplasm; } \\
\text { intracellular } \\
\text { organelle }\end{array}$ & $\begin{array}{l}\text { proteasome } \\
\text { binding }\end{array}$ & 0.035 & 0.597 \\
\hline 32 & E1B8X6 & $\begin{array}{l}\text { Uncharacterized } \\
\text { protein }\end{array}$ & transport; & $\begin{array}{l}\text { Intracellular; } \\
\text { lysosome }\end{array}$ & - & 0.009 & 0.607 \\
\hline 33 & A5PJE0 & $\begin{array}{l}\text { Glutathione } \\
\text { S-transferase }\end{array}$ & metabolic process & $\begin{array}{l}\text { intracellular } \\
\text { part }\end{array}$ & $\begin{array}{l}\text { transferase } \\
\text { activity }\end{array}$ & 0.016 & 0.607 \\
\hline 34 & A7MBJ4 & $\begin{array}{l}\text { Receptor-type } \\
\text { tyrosine-protein } \\
\text { phosphatase F }\end{array}$ & $\begin{array}{l}\text { regulation of } \\
\text { response to } \\
\text { stimulus; cell } \\
\text { development }\end{array}$ & membrane & anion bindin & 0.025 & 0.608 \\
\hline 35 & Q5E9D6 & $\begin{array}{l}\text { Haloacid } \\
\text { dehalogenase-like } \\
\text { hydrolase } \\
\text { domain-containing } \\
\text { protein } 3\end{array}$ & $\begin{array}{l}\text { small molecule } \\
\text { metabolic process }\end{array}$ & - & $\begin{array}{l}\text { hydrolase activity; } \\
\text { phosphatase } \\
\text { activity }\end{array}$ & 0.015 & 0.612 \\
\hline 36 & F1MD78 & $\begin{array}{l}\text { Uncharacterized } \\
\text { protein }\end{array}$ & - & $\begin{array}{l}\text { intracellular } \\
\text { organelle } \\
\text { part; nuclear } \\
\text { part }\end{array}$ & - & 0.015 & 0.614 \\
\hline 37 & P34955 & $\begin{array}{l}\text { Alpha-1-antiprotein } \\
\text { ase }\end{array}$ & $\begin{array}{l}\text { regulation of } \\
\text { metabolic process; } \\
\text { negative regulation } \\
\text { of catalytic activity }\end{array}$ & $\begin{array}{l}\text { endoplasmic } \\
\text { reticulum; } \\
\text { intracellular } \\
\text { organelle }\end{array}$ & $\begin{array}{l}\text { glycoprotein } \\
\text { binding; enzyme } \\
\text { binding; enzyme } \\
\text { inhibitor activity }\end{array}$ & 0.044 & 0.617 \\
\hline 38 & A6QPZ3 & NUP35 protein & transport & membrane & - & 0.010 & 0.619 \\
\hline 39 & Q9MYM4 & $\begin{array}{l}\text { Lysosomal } \\
\text { alpha-glucosidase }\end{array}$ & metabolic process & $\begin{array}{l}\text { intracellular } \\
\text { organelle; } \\
\text { extracellular } \\
\text { organelle }\end{array}$ & hydrolase activity & 0.025 & 0.625 \\
\hline 40 & F1MJB0 & $\begin{array}{l}\text { Uncharacterized } \\
\text { protein }\end{array}$ & - & - & - & 0.013 & 0.626 \\
\hline 41 & E1BI31 & $\begin{array}{l}\text { Uncharacterized } \\
\text { protein }\end{array}$ & $\begin{array}{l}\text { positive regulation } \\
\text { of immune system } \\
\text { process }\end{array}$ & $\begin{array}{l}\text { intracellular } \\
\text { organelle; } \\
\text { membrane }\end{array}$ & enzyme binding & 0.040 & 0.629 \\
\hline 42 & Q3T0Y5 & $\begin{array}{l}\text { Proteasome subunit } \\
\text { alpha type- } 2\end{array}$ & $\begin{array}{l}\text { cellular protein } \\
\text { metabolic process; }\end{array}$ & $\begin{array}{l}\text { extracellular } \\
\text { vesicle; }\end{array}$ & $\begin{array}{l}\text { endopeptidase } \\
\text { activity }\end{array}$ & 0.031 & 0.631 \\
\hline
\end{tabular}




\begin{tabular}{|c|c|c|c|c|c|c|c|}
\hline & & & $\begin{array}{l}\text { multi-organism } \\
\text { process }\end{array}$ & $\begin{array}{l}\text { intracellular } \\
\text { organelle }\end{array}$ & & & \\
\hline 43 & F1MNT4 & $\begin{array}{l}\text { Uncharacterized } \\
\text { protein }\end{array}$ & $\begin{array}{l}\text { tissue development; } \\
\text { regulation of } \\
\text { cellular process }\end{array}$ & $\begin{array}{l}\text { extracellular } \\
\text { matrix }\end{array}$ & integrin binding & 0.002 & 1.502 \\
\hline 44 & G3X839 & $\begin{array}{l}\text { Up-regulator of cell } \\
\text { proliferation }\end{array}$ & apoptotic process & - & - & 0.011 & 1.504 \\
\hline 45 & F1MPD4 & $\begin{array}{l}\text { Uncharacterized } \\
\text { protein }\end{array}$ & - & - & - & 0.000 & 1.508 \\
\hline 46 & G3MZ27 & $\begin{array}{l}\text { Uncharacterized } \\
\text { protein }\end{array}$ & $\begin{array}{l}\text { single-organism } \\
\text { process }\end{array}$ & $\begin{array}{l}\text { membrane } \\
\text { part }\end{array}$ & $\begin{array}{l}\text { trans- } \\
\text { membrane } \\
\text { signaling receptor } \\
\text { activity }\end{array}$ & 0.003 & 1.511 \\
\hline 47 & F1MHC3 & CD44 antigen & cell adhesion & $\begin{array}{l}\text { integral } \\
\text { component } \\
\text { of } \\
\text { membrane }\end{array}$ & binding & 0.000 & 1.512 \\
\hline 48 & G3X6B3 & $\begin{array}{l}\text { Uncharacterized } \\
\text { protein }\end{array}$ & $\begin{array}{l}\text { immune system } \\
\text { process }\end{array}$ & membrane & $\begin{array}{l}\text { nucleic } \quad \text { acid } \\
\text { binding }\end{array}$ & 0.041 & 1.515 \\
\hline 49 & E1BBW0 & $\begin{array}{l}\text { Leucine-rich repeat } \\
\text { flightless-interacting } \\
\text { protein } 2\end{array}$ & - & $\begin{array}{l}\text { cytoplasm; } \\
\text { membrane }\end{array}$ & protein binding & 0.009 & 1.530 \\
\hline 50 & A6QQN2 & $\begin{array}{l}\text { Tyrosine-protein } \\
\text { phosphatase } \\
\text { non-receptor type }\end{array}$ & $\begin{array}{l}\text { apoptotic signaling } \\
\text { pathway }\end{array}$ & $\begin{array}{l}\text { endoplasmic } \\
\text { reticulum }\end{array}$ & $\begin{array}{l}\text { phosphatase } \\
\text { activity }\end{array}$ & 0.006 & 1.537 \\
\hline 51 & G5E6P8 & $\begin{array}{l}\text { Uncharacterized } \\
\text { protein }\end{array}$ & $\begin{array}{l}\text { lipid metabolic } \\
\text { process }\end{array}$ & membrane & hydrolase activity & 0.016 & 1.537 \\
\hline 52 & A5PKJ4 & $\begin{array}{l}\text { Mitogen-activated } \\
\text { protein kinase } 7\end{array}$ & $\begin{array}{l}\text { intracellular } \\
\text { transport }\end{array}$ & cytoplasm & kinase binding & 0.044 & 1.541 \\
\hline 53 & Q0VCX2 & $\begin{array}{l}78 \mathrm{kDa} \text { glucose- } \\
\text { regulated protein }\end{array}$ & $\begin{array}{l}\text { regulation of cell } \\
\text { migration }\end{array}$ & $\begin{array}{l}\text { cytoplasmic } \\
\text { vesicle }\end{array}$ & $\begin{array}{l}\text { small molecule } \\
\text { binding }\end{array}$ & 0.000 & 1.542 \\
\hline 54 & A6QQ16 & NSL1 protein & $\begin{array}{l}\text { primary metabolic } \\
\text { process }\end{array}$ & $\begin{array}{l}\text { intracellular } \\
\text { organelle }\end{array}$ & hydrolase activity & 0.037 & 1.544 \\
\hline 55 & P17248 & $\begin{array}{l}\text { Tryptophan--tRNA } \\
\text { ligase, cytoplasmic }\end{array}$ & metabolic process & $\begin{array}{l}\text { intracellular } \\
\text { organelle }\end{array}$ & binding & 0.000 & 1.544 \\
\hline 56 & F1MWL1 & $\begin{array}{l}\text { Uncharacterized } \\
\text { protein }\end{array}$ & $\begin{array}{l}\text { cellular protein } \\
\text { metabolic process }\end{array}$ & $\begin{array}{l}\text { actin } \\
\text { cytoskeleton }\end{array}$ & hydrolase activity & 0.000 & 1.545 \\
\hline 57 & E1B7E1 & $\begin{array}{l}\text { Uncharacterized } \\
\text { protein }\end{array}$ & $\begin{array}{l}\text { regulation of } \\
\text { developmental } \\
\text { process }\end{array}$ & $\begin{array}{l}\text { intracellular } \\
\text { organelle }\end{array}$ & protein binding & 0.027 & 1.546 \\
\hline 58 & Q58CU2 & $\begin{array}{l}\text { Band } \\
\text { protein } 5\end{array}$ & & $\begin{array}{l}\text { cytoplasm; } \\
\text { membrane }\end{array}$ & protein binding & 0.011 & 1.555 \\
\hline 59 & Q9BE40 & Myosin-1 & metabolic process & $\begin{array}{l}\text { intracellular } \\
\text { organelle }\end{array}$ & binding & 0.027 & 1.558 \\
\hline 60 & A6QL95 & $\begin{array}{l}\text { Dolichyl-diphospho } \\
\text { oligosaccharide--pro } \\
\text { tein } \\
\text { glycosyltransferase } \\
\text { subunit } 1\end{array}$ & $\begin{array}{l}\text { cellular } \\
\text { biosynthetic } \\
\text { process }\end{array}$ & $\begin{array}{l}\text { endoplasmic } \\
\text { reticulum }\end{array}$ & catalytic activity & 0.027 & 1.560 \\
\hline 61 & A8E641 & DPYSL5 protein & developmental & cytoplasm & hydrolase activity & 0.000 & 1.560 \\
\hline
\end{tabular}




\begin{tabular}{|c|c|c|c|c|c|c|c|}
\hline & & & process & & & & \\
\hline 62 & Q58D63 & $\begin{array}{ll}\text { MOB } & \text { kinase } \\
\text { activator 3A } & \end{array}$ & & intracellular & cation binding & 0.001 & 1.561 \\
\hline 63 & Q08E24 & $\begin{array}{l}\text { Store-operated } \\
\text { calcium } \\
\text { entry-associated } \\
\text { regulatory factor }\end{array}$ & $\begin{array}{l}\text { regulation } \\
\text { transport }\end{array}$ & $\begin{array}{l}\text { intracellular } \\
\text { organelle }\end{array}$ & - & 0.041 & 1.565 \\
\hline 64 & Q08DW2 & $\begin{array}{l}\text { Phosphoribosyl } \\
\text { pyrophosphate } \\
\text { synthase-associated } \\
\text { protein } 1\end{array}$ & $\begin{array}{l}\text { compound } \\
\text { metabolic process }\end{array}$ & - & $\begin{array}{l}\text { transferase } \\
\text { activity }\end{array}$ & 0.005 & 1.578 \\
\hline 65 & F1MHH5 & $\begin{array}{l}\text { Uncharacterized } \\
\text { protein }\end{array}$ & cell-cell adhesion & membran & $\begin{array}{l}\text { signaling receptor } \\
\text { activity }\end{array}$ & 0.038 & 1.580 \\
\hline 66 & F1MMV5 & $\begin{array}{l}\text { Nuclear } \\
\text { speckle-splicing } \\
\text { regulatory protein } 1\end{array}$ & metabolic process & nucleus & binding & 0.002 & 1.583 \\
\hline 67 & A4FV01 & SF3B2 protein & - & intracellular & $\begin{array}{l}\text { nucleic acid } \\
\text { binding }\end{array}$ & 0.027 & 1.585 \\
\hline 68 & A7E3V7 & $\begin{array}{l}\text { Guanine nucleotide- } \\
\text { binding protein, } \\
\text { beta-1 subunit }\end{array}$ & $\begin{array}{l}\text { cellular response to } \\
\text { organic substance }\end{array}$ & $\begin{array}{l}\text { membrane } \\
\text { part }\end{array}$ & hydrolase activity & 0.004 & 1.604 \\
\hline 69 & A7YY73 & $\begin{array}{l}\text { Transcription factor } \\
\text { MafF }\end{array}$ & organ development & intracellula & $\begin{array}{l}\text { nucleic acid } \\
\text { binding }\end{array}$ & 0.001 & 1.610 \\
\hline 70 & G3MZZ3 & $\begin{array}{l}\text { Sorting and } \\
\text { assembly machinery } \\
\text { component } 50 \\
\text { homolog }\end{array}$ & $\begin{array}{l}\text { protein complex } \\
\text { biogenesis }\end{array}$ & $\begin{array}{l}\text { integral } \\
\text { component } \\
\text { of } \\
\text { membrane }\end{array}$ & - & 0.001 & 1.611 \\
\hline 71 & P01131 & $\begin{array}{l}\text { Low-density } \\
\text { lipoprotein receptor }\end{array}$ & $\begin{array}{l}\text { lipid metabolic } \\
\text { process }\end{array}$ & $\begin{array}{l}\text { plasma } \\
\text { membrane } \\
\text { raft }\end{array}$ & - & 0.003 & 1.612 \\
\hline 72 & A4IFH7 & MKK3 protein & $\begin{array}{l}\text { inflammatory } \\
\text { response }\end{array}$ & intracellular & $\begin{array}{l}\text { protein kinase } \\
\text { activity }\end{array}$ & 0.002 & 1.619 \\
\hline 73 & A6QPP3 & $\begin{array}{l}\text { Fibroblast growth } \\
\text { factor }\end{array}$ & $\begin{array}{l}\text { single- } \\
\text { organism } \\
\text { developmental } \\
\text { process }\end{array}$ & $\begin{array}{l}\text { plasma } \\
\text { membrane }\end{array}$ & $\begin{array}{l}\text { kinase regulator } \\
\text { activity }\end{array}$ & 0.029 & 1.619 \\
\hline 74 & E1BIU0 & $\begin{array}{l}\text { Uncharacterized } \\
\text { protein }\end{array}$ & $\begin{array}{l}\text { cellular protein } \\
\text { localization }\end{array}$ & membrane & binding & 0.000 & 1.630 \\
\hline 75 & E1BJL9 & $\begin{array}{l}\text { Uncharacterized } \\
\text { protein (Fragment) }\end{array}$ & $\begin{array}{l}\text { regulation of } \\
\text { immune system } \\
\text { process }\end{array}$ & membrane & $\begin{array}{l}\text { cytokine receptor } \\
\text { binding }\end{array}$ & 0.025 & 1.634 \\
\hline 76 & P63009 & $\begin{array}{l}\text { AP-2 complex } \\
\text { subunit beta }\end{array}$ & $\begin{array}{l}\text { intracellular protein } \\
\text { transport }\end{array}$ & membrane & $\begin{array}{l}\text { transporter } \\
\text { activity }\end{array}$ & 0.035 & 1.639 \\
\hline 77 & F1MPF7 & $\begin{array}{l}\text { Uncharacterized } \\
\text { protein }\end{array}$ & $\begin{array}{l}\text { developmental } \\
\text { process }\end{array}$ & $\begin{array}{l}\text { extracellular } \\
\text { organelle }\end{array}$ & binding & 0.001 & 1.653 \\
\hline 78 & P85521 & $\begin{array}{l}\text { Scavenger receptor } \\
\text { cysteine-rich type } 1 \\
\text { protein M130 }\end{array}$ & $\begin{array}{l}\text { inflammatory } \\
\text { response }\end{array}$ & membrane & receptor activity & 0.000 & 1.658 \\
\hline 79 & A4FUG6 & ALG2 protein & $\begin{array}{l}\text { protein metabolic } \\
\text { process }\end{array}$ & $\begin{array}{l}\text { cytoplasmic } \\
\text { part }\end{array}$ & protein binding & 0.000 & 1.660 \\
\hline
\end{tabular}




\begin{tabular}{|c|c|c|c|c|c|c|c|}
\hline 80 & F1MRP6 & $\begin{array}{l}\text { Collagen } \\
\text { alpha-2(XI) chain }\end{array}$ & & $\begin{array}{l}\text { extracellular } \\
\text { region }\end{array}$ & ion binding & 0.001 & 1.668 \\
\hline 81 & E1BMF2 & $\begin{array}{l}\text { Uncharacterized } \\
\text { protein }\end{array}$ & $\begin{array}{l}\text { protein metabolic } \\
\text { process }\end{array}$ & $\begin{array}{l}\text { extracellular } \\
\text { region }\end{array}$ & peptidase activity & 0.002 & 1.677 \\
\hline 82 & F6R9F1 & $\begin{array}{l}\text { Uncharacterized } \\
\text { protein }\end{array}$ & $\begin{array}{l}\text { cellular response to } \\
\text { stimulus }\end{array}$ & intracellular & binding & 0.000 & 1.679 \\
\hline 83 & A8E4N3 & $\begin{array}{l}\text { Radial spoke head } \\
\text { protein } 3 \text { homolog }\end{array}$ & - & - & - & 0.031 & 1.680 \\
\hline 84 & Q32LE9 & $\begin{array}{l}\text { Cysteine and } \\
\text { glycine- } \\
\text { rich protein } 2\end{array}$ & $\begin{array}{l}\text { developmental } \\
\text { process }\end{array}$ & intracellular & ion binding & 0.005 & 1.683 \\
\hline 85 & Q2TA45 & $\begin{array}{l}\text { Arf-GAP domain } \\
\text { and FG } \\
\text { repeat-containing } \\
\text { protein } 1\end{array}$ & $\begin{array}{l}\text { developmental } \\
\text { process }\end{array}$ & $\begin{array}{l}\text { membrane- } \\
\text { bounded } \\
\text { vesicle }\end{array}$ & $\begin{array}{l}\text { enzyme regulator } \\
\text { activity }\end{array}$ & 0.035 & 1.686 \\
\hline 86 & A6QL93 & TACC3 protein & $\begin{array}{l}\text { response to } \\
\text { stimulus }\end{array}$ & $\begin{array}{l}\text { intracellular } \\
\text { organelle }\end{array}$ & binding & 0.000 & 1.687 \\
\hline 87 & P12624 & $\begin{array}{l}\text { Myristoylated } \\
\text { alanine-rich } \\
\text { C-kinase substrate }\end{array}$ & & cytoplasm & protein binding & 0.006 & 1.697 \\
\hline 88 & P33946 & $\begin{array}{l}\text { ER lumen protein- } \\
\text { retaining receptor } 1\end{array}$ & $\begin{array}{l}\text { regulation of } \\
\text { transport }\end{array}$ & $\begin{array}{l}\text { cytoplasmic } \\
\text { part }\end{array}$ & peptide binding & 0.005 & 1.705 \\
\hline 89 & F1MXI0 & Kelch-like protein 9 & metabolic process & $\begin{array}{l}\text { intracellular } \\
\text { part }\end{array}$ & $\begin{array}{l}\text { transferase } \\
\text { activity }\end{array}$ & 0.033 & 1.713 \\
\hline 90 & A2VDK6 & $\begin{array}{l}\text { Wiskott-Aldrich } \\
\text { syndrome protein } \\
\text { fam- } \\
\text { ily member } 2\end{array}$ & cell migration & $\begin{array}{l}\text { extracellular } \\
\text { region part }\end{array}$ & protein binding & 0.006 & 1.717 \\
\hline 91 & G3N121 & $\begin{array}{l}\text { Cytosolic } \\
\text { carboxypeptidase } 3\end{array}$ & $\begin{array}{l}\text { protein metabolic } \\
\text { process }\end{array}$ & cytoplasm & binding & 0.034 & 1.717 \\
\hline 92 & F1MQ43 & $\begin{array}{l}\text { Uncharacterized } \\
\text { protein }\end{array}$ & $\begin{array}{l}\text { regulation of } \\
\text { metabolic process }\end{array}$ & membrane & enzyme binding & 0.000 & 1.737 \\
\hline 93 & Q7SIB2 & $\begin{array}{l}\text { Collagen } \\
\text { alpha-1(IV) chain }\end{array}$ & $\begin{array}{l}\text { single-organism } \\
\text { process }\end{array}$ & $\begin{array}{l}\text { extracellular } \\
\text { region| }\end{array}$ & protein binding & 0.002 & 1.763 \\
\hline 94 & E1BG99 & $\begin{array}{l}\text { Uncharacterized } \\
\text { protein }\end{array}$ & $\begin{array}{l}\text { regulation of } \\
\text { metabolic process }\end{array}$ & - & - & 0.000 & 1.852 \\
\hline 95 & E1B9F3 & $\begin{array}{l}\text { Uncharacterized } \\
\text { protein }\end{array}$ & $\begin{array}{l}\text { cellular } \\
\text { developmental } \\
\text { process }\end{array}$ & cytoplasm & protein binding & 0.000 & 1.863 \\
\hline 96 & E1B7H4 & $\begin{array}{l}\text { Uncharacterized } \\
\text { protein }\end{array}$ & response to stress & cytoplasm & $\begin{array}{l}\text { protein kinase } \\
\text { activity }\end{array}$ & 0.002 & 1.885 \\
\hline 97 & F1MTZ0 & $\begin{array}{l}\text { Protein phosphatase } \\
\text { inhibitor } 2\end{array}$ & $\begin{array}{l}\text { regulation of signal } \\
\text { transduction }\end{array}$ & & $\begin{array}{l}\text { enzyme regulator } \\
\text { activity }\end{array}$ & 0.000 & 1.891 \\
\hline 98 & F1MCR5 & $\begin{array}{l}\text { Fibronectin type } 3 \\
\text { and ankyrin repeat } \\
\text { domains protein } 1\end{array}$ & - & intracellular & - & 0.000 & 1.901 \\
\hline 99 & Q08DQ1 & $\begin{array}{l}\text { Calcium/calmodulin } \\
\text {-dependent protein } \\
\text { kinase I }\end{array}$ & $\begin{array}{l}\text { biosynthetic } \\
\text { process }\end{array}$ & intracellular & $\begin{array}{l}\text { nucleoside } \\
\text { binding }\end{array}$ & 0.001 & 1.927 \\
\hline
\end{tabular}




\begin{tabular}{|c|c|c|c|c|c|c|c|}
\hline 100 & A6QLU8 & Nucleoredoxin & $\begin{array}{l}\text { regulation of } \\
\text { protein metabolic } \\
\text { process }\end{array}$ & cytoplasm & $\begin{array}{l}\text { antioxidant } \\
\text { activity }\end{array}$ & 0.004 & 1.949 \\
\hline 101 & $\mathrm{~F} 1 \mathrm{MX} 40$ & $\begin{array}{l}\text { Uncharacterized } \\
\text { protein }\end{array}$ & metabolic process & $\begin{array}{l}\text { nucleoside } \\
\text { binding }\end{array}$ & $\begin{array}{l}\text { nucleotide } \\
\text { binding }\end{array}$ & 0.000 & 1.959 \\
\hline 102 & Q9TRL9 & $\begin{array}{l}\mathrm{CA}(2+) \text {-dependent } \\
\text { carbohydrate-bindin } \\
\mathrm{g} \text { protein }\end{array}$ & $\begin{array}{l}\text { regulation of } \\
\text { developmental } \\
\text { process }\end{array}$ & nucleus & binding & 0.004 & 1.962 \\
\hline 103 & F1MJZ0 & $\begin{array}{l}\text { Uncharacterized } \\
\text { protein }\end{array}$ & $\begin{array}{l}\text { regulation of } \\
\text { system process }\end{array}$ & membrane & $\begin{array}{l}\text { signaling receptor } \\
\text { activity }\end{array}$ & 0.001 & 1.970 \\
\hline 104 & Q3T0C8 & $\begin{array}{l}\text { PDZ and LIM } \\
\text { domain protein } 2\end{array}$ & & cell junction & cation binding & 0.002 & 1.979 \\
\hline 105 & E1B7M1 & $\begin{array}{l}\text { Uncharacterized } \\
\text { protein }\end{array}$ & $\begin{array}{l}\text { cellular } \\
\text { developmental } \\
\text { process }\end{array}$ & - & $\begin{array}{l}\text { exchange factor } \\
\text { activity }\end{array}$ & 0.022 & 1.998 \\
\hline 106 & F1MQI1 & $\begin{array}{l}\text { Uncharacterized } \\
\text { protein }\end{array}$ & $\begin{array}{l}\text { cellular protein } \\
\text { localization }\end{array}$ & $\begin{array}{l}\text { intracellular } \\
\text { organelle }\end{array}$ & receptor binding & 0.021 & 2.085 \\
\hline 107 & F1MWF0 & $\begin{array}{l}\text { Uncharacterized } \\
\text { protein }\end{array}$ & $\begin{array}{l}\text { regulation of } \\
\text { protein metabolic } \\
\text { process }\end{array}$ & $\begin{array}{l}\text { cytoplasmic } \\
\text { vesicle }\end{array}$ & $\begin{array}{l}\text { phospholipid } \\
\text { binding }\end{array}$ & 0.007 & 2.243 \\
\hline 108 & Q1LZB2 & $\begin{array}{l}\text { NCK adaptor } \\
\text { protein } 1\end{array}$ & $\begin{array}{l}\text { regulation of } \\
\text { signaling }\end{array}$ & $\begin{array}{l}\text { cell-cell } \\
\text { junction }\end{array}$ & $\begin{array}{l}\text { protein kinase } \\
\text { inhibitor activity }\end{array}$ & 0.001 & 2.252 \\
\hline 109 & G3MWY9 & $\begin{array}{l}\text { Sjoegren syndrome } \\
\text { nuclear autoantigen } \\
1 \text { homolog }\end{array}$ & $\begin{array}{l}\text { regulation of } \\
\text { cellular process }\end{array}$ & cytoplasm & protein binding & 0.000 & 2.254 \\
\hline 110 & E1BGM1 & $\begin{array}{l}\text { Uncharacterized } \\
\text { protein }\end{array}$ & - & - & ion binding & 0.001 & 2.294 \\
\hline 111 & E1BM72 & Pescadillo homolog & $\begin{array}{l}\text { primary metabolic } \\
\text { process }\end{array}$ & $\begin{array}{l}\text { Nucleus; } \\
\text { membrane }\end{array}$ & $\begin{array}{l}\text { nucleic acid } \\
\text { bindin }\end{array}$ & 0.028 & 2.434 \\
\hline 112 & A7YW40 & $\begin{array}{l}\text { Transcription } \\
\text { elongation factor } \\
\text { SPT5 }\end{array}$ & metabolic process & $\begin{array}{l}\text { Nucleus; } \\
\text { intracellular }\end{array}$ & binding & 0.000 & 2.604 \\
\hline 113 & F1MHA1 & $\begin{array}{l}\text { Uncharacterized } \\
\text { protein }\end{array}$ & $\begin{array}{l}\text { biological } \\
\text { regulation }\end{array}$ & $\begin{array}{l}\text { intracellular } \\
\text { part }\end{array}$ & $\begin{array}{l}\text { transferase } \\
\text { activity }\end{array}$ & 0.000 & 3.021 \\
\hline 114 & F1MSV7 & $\begin{array}{l}\text { Uncharacterized } \\
\text { protein }\end{array}$ & $\begin{array}{l}\text { regulation of } \\
\text { secretion }\end{array}$ & intracellular & metal ion binding & 0.008 & 3.075 \\
\hline 115 & G3X752 & $\begin{array}{l}\text { Vesicle-associated } \\
\text { membrane protein } 3\end{array}$ & $\begin{array}{l}\text { regulation of } \\
\text { secretion }\end{array}$ & cytoplasm & binding & 0.000 & 3.850 \\
\hline 116 & F1MJN7 & $\begin{array}{l}\text { Uncharacterized } \\
\text { protein }\end{array}$ & - & - & binding & 0.000 & 3.923 \\
\hline
\end{tabular}

\section{GO annotations of the DEPs}

The results of the GO enrichment analysis of the biological process showed that the DEPs were significantly enriched in five processes. These processes included single organism process, response to a stimulus, metabolic process, cell process, and biological regulation. The proteins involved in the biological regulation process were found most, followed by those involved in the stimulation response process. In this study, the proteins involved in the stimulation response process mainly included tyrosine phosphatase, signal transduction protein 1, Rab5 GDP/GTP 
conversion factor 1, interleukin-13 (IL-13), mitogen-activated protein kinase 7 (MAPK7), FOX transcription inhibitory factor 3(Foxp3), calcium phosphate, protein tyrosine phosphatase protein receptor, MAP3K10, human telomerase reverse transcriptase, and SSNA1. IL-13 is the most important inflammatory factor that causes airway inflammation. It plays a key role in the occurrence of chronic airway inflammatory disease, which induces high secretion of mucus. Foxp3 is a member of the Fox transcription factor family that plays an important role in maintaining the immune function of the body[17]. The DEPs in BPIV3-infected MDBK cells may cause the initial cellular stress response. The precise role of these DEPs in the BPIV3 infection process need to be further investigated.

\section{Kyoto Encyclopedia of Genes and Genomes (KEGG) pathway analysis of the DEPs}

The KEGG pathway database is a collection map based on the molecular interaction pathways and cellular response networks. The DEPs were identified and mapped to six KEGG pathways, including metabolism, cellular processes, organismal systems, environmental information process, genetic information process, and disease pathways. The organismal systems and disease pathways were enrichment pathways, represented by 37 and 43 pathway groups, respectively.

In the metabolic pathways, the DEPs participated in 13 pathways related to the metabolism of glucose, lipid, amino acid, and nucleotides (Fig 4-A). These pathways affect the metabolism of three major nutrients in cells. The cellular processes involved ten pathways (Fig.4-B), including the Focal adhesion pathway and the Phagosome pathway, both of which are involved in the viral infection process; the integrin protein is the key protein in these two pathways. The lysosome pathway, phagosome pathway, and autophagy are involved in the autophagy process of virus infection. The annotated proteins in the category of genetic information processing play a role in the synthesis, transport, proteolysis, and spliceosome of cells (Fig.4-D). The annotated proteins in the organismal systems category were related to antigen processing and presentation, NOD-like receptor signaling, Toll-like receptor signaling, complement and coagulation cascades, and Th1 and Th2 cell differentiation pathway groups. These pathways were primarily related to the immune response of the host to virus infection (Fig.4-E). The DEPs annotated in the disease category are shown in Fig.4-F. There are ten pathways associated with infectious diseases, five of which are associated with viral infections.

According to the profiling of DEPs, a relatively large number of proteins matched with the MAPK signaling pathway, including FGF13, ERK5, and MKK3. The KEGG pathway analysis revealed that MKK3 is involved in 14 pathways, indicating that MKK3 is a key regulatory protein during BPIV3 infection of MDBK cells (Fig. 4-C).

\section{Validation of the selected proteins by real-time quantitative PCR (qRT-PCR)}

To verify the DEPs identified by iTRAQ, the transcriptional levels of eight proteins were measured by qRT-PCR. In this study, eight proteins were randomly selected for qRT-PCR. The 
four upregulated proteins included AP-2 complex subunit beta protein (AP-2), FGF13, myristoylated alanine-rich C-kinase substrate (MARCS), and MKK3 proteins. The four downregulated proteins included MHC class II (MHCII), glutathione S-transferase (GSTA1), selenium protein $\mathrm{P}$ (SepP), and tissue factor pathway inhibitor (TFPI). As shown in Fig.5, the expression levels of these genes were consistent with the iTRAQ results. The results of qRT-PCR further verified the reliability of the iTRAQ experiment.

\section{The effect of the p38 MAPK pathway on BPIV3 replication}

\section{BPIV3 infection activates the p38 MAPK pathway}

The MAPK pathway plays various roles in intracellular signaling network. MKK3 and MKK6 are recognized as upstream kinases of $\mathrm{p} 38$. The results of proteomics analysis showed that the MKK3 level was significantly upregulated after BPIV3 infection (Fig. 4C). Virus infection is considered as an extracellular stimulant that can activate p38 MAPK pathway[18, 19]. It should be investigated whether BPIV3 infection activated the p38 MAPK pathway after MKK3 activation.

The expression of MKK3, p38, and phospho-p38 in BPIV3-infected cells was detected by western blotting assay. Cell samples were collected at 6, 12, and $24 \mathrm{~h}$ after BPIV3 infection. Compared to the mock group, the MKK3 expression levels were increased at different infection time points in the infected group. No change was observed in the p38 protein expression level, while the phospho-p38 expression level was significantly higher in the infected group than in the mock group at 12 and $24 \mathrm{~h}$ after BPIV3 infection (Fig. 6). Thus, BPIV3 infection induced MKK3 activation and p38 phosphorylation. The MKK3 expression level was consistent with previous proteomics results, which further verified the reliability of proteomics analysis.

\section{The effect of inhibiting p38 MAPK activation on BPIV3 replication}

To investigate whether the activation of the p38 MAPK pathway promotes BPIV3 proliferation, the cells were treated with SB202190, an inhibitor of the p38 MAPK pathway, $1 \mathrm{~h}$ before infection. MDBK cells were treated with SB202190 at 1.25, 5, and $10 \mathrm{M}$ concentrations. Cell samples were collected at $24 \mathrm{~h}$ after infection $(\mathrm{MOI}=1)$.

The results are shown in Fig. 7. BPIV3 infection induced the phosphorylation of p38. After treatment with the inhibitor SB202190, the expression level of p38 was significantly decreased in a dose-dependent manner, indicating that the phosphorylation of p38 was inhibited by SB202190(Fig.7-A). The results are shown in Fig. 7B. The BPIV3 virus titer decreased by 1.8 $\log \mathrm{TCID}_{50} / \mathrm{mL}$ after treatment with $10 \mathrm{M}$ SB202190, indicating that the p38 MAPK pathway participates in the replication of BPIV3. The results showed that SB202190 could inhibit the proliferation of BPIV3. Thus, BPIV3 activated the p38 MAPK signaling pathway that is involved in its replication.

\section{Discussion}


iTRAQ LC-MS/MS is a powerful analytical tool for quantitative proteomics analysis that has been widely used in many studies [20-23]. Gray et.al used 2D gel electrophoresis proteomic to investigate in vitro cellular responses during BPIV3 infection [24]. In the present study, we first applied the iTRAQ LC-MS/MS approach to determine the profiles of DEPs in MDBK cells infected with BPIV3 at various time points of infection. A total of 116 DEPs were identified at 24 $\mathrm{h}$ after infection based on a fold change of $\geq 1.5$ and $\mathrm{p}$-value $<0.05$ (data not show). On the basis of GO analysis, the DEPs were classified into 19, 11, and 9 categories for biological processes, cellular components, and molecular functions, respectively (Fig. 3). The pathway analysis identified the pathways based on the number of DEPs (Fig. 4). These data could provide a basis for understanding the pathogenetic mechanisms of BPIV3 infection.

The results showed that the PI3K-Akt signaling pathway and the MAPK signaling pathway play important roles in the progression of BPIV3 infection. According to the profiles of DEPs in these two signaling pathways, only ITGB3 was downregulated, while the remaining proteins were upregulated. The analysis of the DEPs in these pathways showed that the number of matched proteins in the MAPK signaling pathway was relatively large, including FGF13, ERK5, and MKK3. The KEGG pathway results indicated that MKK3 was involved in 14 pathways, which suggested that MKK3 is a key regulatory protein during BPIV3 infection. Previous studies have shown that the MAPK signaling pathway is a target of respiratory viruses, which regulates various stages of the infection process[25, 26].

The MAPK cascade plays various roles in intracellular signaling network pathways. MKK3 and MKK6 are recognized as upstream kinases of p38 that can directly phosphorylate tyrosine and serine/threonine residues to activate p38 [27]. Viral infection is thought to be an extracellular stimulant that activates this pathway. In infectious salmon anemia virus (ISAV) infection, immunohistochemical detection showed that the phosphorylation level of p-ERk1/p-p38 in the lungs of sheep infected with JSRV was significantly increased compared to that in healthy sheep [18]. In HBV-infected HuH-7 cells, the results showed that HBV replication activated JNK and p38 [30]. In our proteomics study, the MKK3 level was significantly upregulated $24 \mathrm{~h}$ after BPIV3 infection as compared to that in the control group. Therefore, we detected the expression level of the p38 MAPK pathway proteins after BPIV3 infection.

First, we investigated whether BPIV3 infection activates the p38 MAPK pathway. The results showed that BPIV3 induces the phosphorylation of p38 after infection. Compared to the control group, the phosphorylated p38 expression was significantly increased after $6 \mathrm{~h}$ of BPIV3 infection, demonstrating that BPIV3 can induce the activation of the p38 MAPK pathway in the early stage of infection.

Multiple extracellular stresses activate the MKK3-p38 MAPK cascade, including specific antigens, proinflammatory cytokines, ultraviolet light, heat shock, and other stress responses[28]. In accordance with the results of the mechanism of Coxsackie virus activation of p38 MAPK, we hypothesized that in the early stage of infection [29], the binding of BPIV3 HN protein to the 
receptor on the surface of the cell membrane induced membrane fusion, and the cascade reaction of MKK3-p38 MAPK was temporarily activated. The progression of BPIV3 infection was gradually prolonged, and the phosphorylation of p38 MAPK was significantly increased $24 \mathrm{~h}$ after infection. In the late stage of infection, p38 was still continuously activated, which was speculated to be due to the release of proinflammatory cytokines induced by BPIV3 infection; the release of proinflammatory cytokines into the extracellular domain bound to the receptor further enhanced the activation of the p38 MAPK pathway[30, 31].

Many studies have shown that $\mathrm{p} 38$ is required for the replication of viruses. The activation of the MAPK pathways by viruses such as stimulates the JNK and p38 MAPK pathways to promote the release of virions[29]. In porcine reproductive and respiratory syndrome virus infection, the virus replication was inhibited after inhibition of the JNK and p38 pathways [32]. The same results were noted in PEDV infection[33]. To detect the role of the p38 MAPK pathway in BPIV3 replication, virus titer and CPE were analyzed. The results showed that the inhibitor SB202190 significantly inhibited virus replication in a dose-dependent manner. It was also found that $\mathrm{p} 38$ expression was inhibited after treatment with SB202190. Compared with the untreated group, virus titer was significantly decreased after treatment of the cells with the inhibitor. The inhibitor also showed a significant inhibitory effect on virus-induced CPE in a dose-dependent manner. These results revealed that the activation of the p38 MAPK pathway facilitated replication of BPIV3.

\section{Conclusion}

In this study, DEPs in BPIV3-infected MDBK cells were identified and quantitatively analyzed by iTRAQ and LC-MS-based proteomics analysis. Most of the DEPs were proteins related to inflammatory response, immune response, and lipid metabolism. Although many significantly up- or downregulated proteins and pathways are closely related to the symptoms or pathological responses to BPIV3 infection, further functional investigations are required to understand the pathogenic mechanisms and molecular responses of host cells to BPIV3 infection.

The results of the present study indicated that BPIV3 infection activates the p38 MAPK pathway, which is essential for its replication. Proteomics and western blot analyses showed that BPIV3 infection activated the p38 MAPK signaling pathway. Our future research will focus on which step of virus replication is affected by p38 activation.

\section{Abbreviations}

BPIV3: Bovine parainfluenza virus type 3; BRDC: bovine respiratory disease complex; iTRAQ: isobaric tags for relative and absolute quantitation analysis; DEPs: differentially expressed proteins; TGEV: transmissible gastroenteritis virus; PEDV: porcine epidemic diarrhea virus; BRSV: bovine respiratory syncytial virus; DMEM:Dulbecco's modified Eagle's medium; FBS:fetal bovine serum; CPE:cytopathic effect; GO: Gene Ontology; IFA: indirect immunofluorescent assay; MOI:multiplicity of infection; IL-13:interleukin-13; MAPK7: mitogen- 
activated protein kinase 7; Foxp3: FOX transcription inhibitory factor 3; MARCS: myristoylated alanine-rich C-kinase substrate; MHCII: MHC class II; GSTA1: glutathione S-transferase; SepP: selenium protein P; TFPI: tissue factor pathway inhibitor.

\section{Declarations}

\section{Acknowledgments}

Not applicable.

\section{Funding}

This project was supported by the Heilongjiang Bayi Agricultural University natural science talent project (ZRCQC201808), Heilongjiang Agricultural Administration Bureau scientific research projects (HKKYZD190305), Post-doctoral Scientific Foundation of HeiLongJiang Province (LBH-Z20204), Heilongjiang Bayi Agricultural University Doctor's Research Foundation, (XDB201816), Heilongjiang Bayi Agricultural University Scientific Research Team Support project (TDJH201904).

\section{Authors' contributions}

All authors revised the manuscript.

\section{Availability of data and material}

Not applicable.

\section{Ethics approval and consent to participate}

Not applicable.

\section{Consent to publication}

Not applicable.

\section{Competing interests}

The authors declare that there are no conficts of interest.

\section{Author details}

a College of Life Science and Biotechnology, Heilongjiang Bayi Agricultural University, Daqing 163319, China. b College of Animal Science and Veterinary Medicine, Heilongjiang Bayi Agricultural University, Daqing 163319, China . c Department of Nephrology, The Fifth Affiliated Hospital of Harbin Medical University, Daqing 163319, China

\section{References}

1. Kale $\mathrm{M}$, Dylek $\mathrm{O}$, Sybel $\mathrm{H}$, et al. Some viral and bacterial respiratory tract infections of dairy cattle during the summer season. Acta Vet-Beogr 2013, 63(2-3):227-236.

2. Kirchhoff J, Uhlenbruck S, Goris K, et al. Three viruses of the bovine respiratory disease complex apply different strategies to initiate infection. Vet Res 2014, 45:12.

3. Grissett GP, White BJ, Larson RL. Structured Literature Review of Responses of Cattle to Viral 
and Bacterial Pathogens Causing Bovine Respiratory Disease Complex. J Vet Intern Med 2015, 29(3):770-780.

4. Ellis JA. Bovine Parainfluenza-3 Virus. Vet Clin N Am-Food Anim Pract 2010, 26(3):575-+.

5. Durbin AP, McAuliffe JM, Collins PL, et al. Mutations in the $C, D$, and $V$ open reading frames of human parainfluenza virus type 3 attenuate replication in rodents and primates. Virology 1999, 261(2):319-330.

6. Bousse T, Takimoto T. Mutation at residue 523 creates a second receptor binding site on human parainfluenza virus type 1 hemagglutinin-neuraminidase protein. Journal of Virology 2006, 80(18):9009-9016.

7. Jardetzky TS, Lamb RA. Activation of paramyxovirus membrane fusion and virus entry. Curr Opin Virol 2014, 5:24-33.

8. Gerold G, Bruening J, Pietschmann T. Decoding protein networks during virus entry by quantitative proteomics. Virus Res 2016, 218:25-39.

9. Seggerson K, Tang LJ, Moss EG. Two genetic circuits repress the Caenorhabditis elegans heterochronic gene lin-28 after translation initiation. Dev Biol 2002, 243(2):215-225.

10. An K, Fang LR, Luo R, et al. Quantitative Proteomic Analysis Reveals That Transmissible Gastroenteritis Virus Activates the JAK-STAT1 Signaling Pathway. J Proteome Res 2014, 13(12):5376-5390.

11. Sun DB, Shi HY, Guo DH, et al. Analysis of protein expression changes of the Vero E6 cells infected with classic PEDV strain CV777 by using quantitative proteomic technique. J Virol Methods 2015, 218:27-39.

12. Li LY, Yu LY, Hou XL. Cholesterol-rich lipid rafts play a critical role in bovine parainfluenza virus type 3 (BPIV3) infection. Res Vet Sci 2017, 114:341-347.

13. Zhu YM, Shi HF, Gao YR, et al. Isolation and genetic characterization of bovine parainfluenza virus type 3 from cattle in China. Vet Microbiol 2011, 149(3-4):446-451.

14. Chowdhury SI, Coats J, Neis RA, et al. A bovine herpesvirus type 1 mutant virus with truncated glycoprotein $\mathrm{E}$ cytoplasmic tail has defective anterograde neuronal transport in rabbit dorsal root ganglia primary neuronal cultures in a microfluidic chamber system. J Neurovirol 2010, 16(6):457-465.

15. Yazici Z, Ozan E, Tamer C, et al. Circulation of Indigenous Bovine Respiratory Syncytial Virus Strains in Turkish Cattle: The First Isolation and Molecular Characterization. Animals 2020, 10(9):10.

16. Guo XZ, Hu H, Chen FZ, et al. iTRAQ-based comparative proteomic analysis of Vero cells infected with virulent and CV777 vaccine strain-like strains of porcine epidemic diarrhea virus. J Proteomics 2016, 130:65-75.

17. Khattri R, Cox T, Yasayko SA, et al. An essential role for Scurfin in CD4(+)CD25(+)T regulatory cells. J Immunol 2017, 198(3):993-998.

18. Olavarria VH, Recabarren P, Fredericksen F, et al. ISAV infection promotes apoptosis of SHK-1 cells through a ROS/p38 MAPK/Bad signaling pathway. Mol Immunol 2015, 64(1):1-8.

19. Fu YL, Yip A, Seah PG, et al. Modulation of inflammation and pathology during dengue virus infection by p38 MAPK inhibitor SB203580. Antiviral Res 2014, 110:151-157.

20. Li XF, Wang Q, Gao YN, et al. Quantitative iTRAQ LC-MS/MS Proteomics Reveals the Proteome Profiles of DF-1 Cells after Infection with Subgroup J Avian Leukosis Virus. Biomed Res Int 2015, 2015:10. 
21. Lu Q, Bai J, Zhang LL, et al. Two-Dimensional Liquid Chromatography-Tandem Mass Spectrometry Coupled with Isobaric Tags for Relative and Absolute Quantification (iTRAQ) Labeling Approach Revealed First Proteome Profiles of Pulmonary Alveolar Macrophages Infected with Porcine Reproductive and Respiratory Syndrome Virus. J Proteome Res 2012, 11(5):2890-2903.

22. Hu F, Li YF, Yu KX, et al. Proteome analysis of reticuloendotheliosis-virus-infected chicken embryo fibroblast cells through iTRAQ-based quantitative proteomics. Arch Virol 2019, 164(12):2995-3006.

23. Zhong CY, Li JZ, Mao L, et al: Proteomics analysis reveals heat shock proteins involved in caprine parainfluenza virus type 3 infection. BMC Vet Res 2019, 15:14.

24. Gray DW, Welsh MD, Doherty $S$, et al. Identification of candidate protein markers of Bovine Parainfluenza Virus Type 3 infection using an in vitro model. Vet Microbiol 2017, 203:257-266.

25. Wang C, Wei D, Xu M, et al. The Role of p38MAPK in Acute Lung Injury Induced by H9N2 Influenza Virus Isolated from Swine. Acta Veterinaria et Zootechnica Sinica 2014, 45(2):281-288.

26. Lee N, Wong CK, Chan PKS, Lun SWM, et al. Hypercytokinemia and hyperactivation of phospho-p38 mitogen-activated protein kinase in severe human influenza a virus infection. Clin Infect Dis 2007, 45(6):723-731.

27. Coskun $\mathrm{M}$, Olsen J, Seidelin JB, Nielsen $\mathrm{OH}$. MAP kinases in inflammatory bowel disease. Clin Chim Acta 2011, 412(7-8):513-520.

28. Gautier A, Deiters A, Chin JW. Light-Activated Kinases Enable Temporal Dissection of Signaling Networks in Living Cells. J Am Chem Soc 2011, 133(7):2124-2127.

29. Si XN, Luo HL, Morgan A, Zhang JC, et al. Stress-activated protein kinases are involved in coxsackievirus B3 viral progeny release. Journal of Virology 2005, 79(22):13875-13881.

30. Pettus LH, Wurz RP. Small Molecule p38 MAP Kinase Inhibitors for the Treatment of Inflammatory Diseases: Novel Structures and Developments During 2006-2008. Current Topics in Medicinal Chemistry 2008, 8(16):1452-1467.

31. Choi MS, Heo J, Yi CM, Ban J, et al. A novel p38 mitogen activated protein kinase (MAPK) specific inhibitor suppresses respiratory syncytial virus and influenza $A$ virus replication by inhibiting virus-induced p38 MAPK activation. Biochem Biophys Res Commun 2016, 477(3):311-316.

32. An TQ, Li JN, Su CM, Yoo D. Molecular and Cellular Mechanisms for PRRSV Pathogenesis and Host Response to Infection. Virus Res 2020, 286:11.

33. Lee $\mathrm{C}, \mathrm{Kim} \mathrm{Y}$, Jeon JH. JNK and p38 mitogen-activated protein kinase pathways contribute to porcine epidemic diarrhea virus infection. Virus Res 2016, 222:1-12. 


\section{Figures}
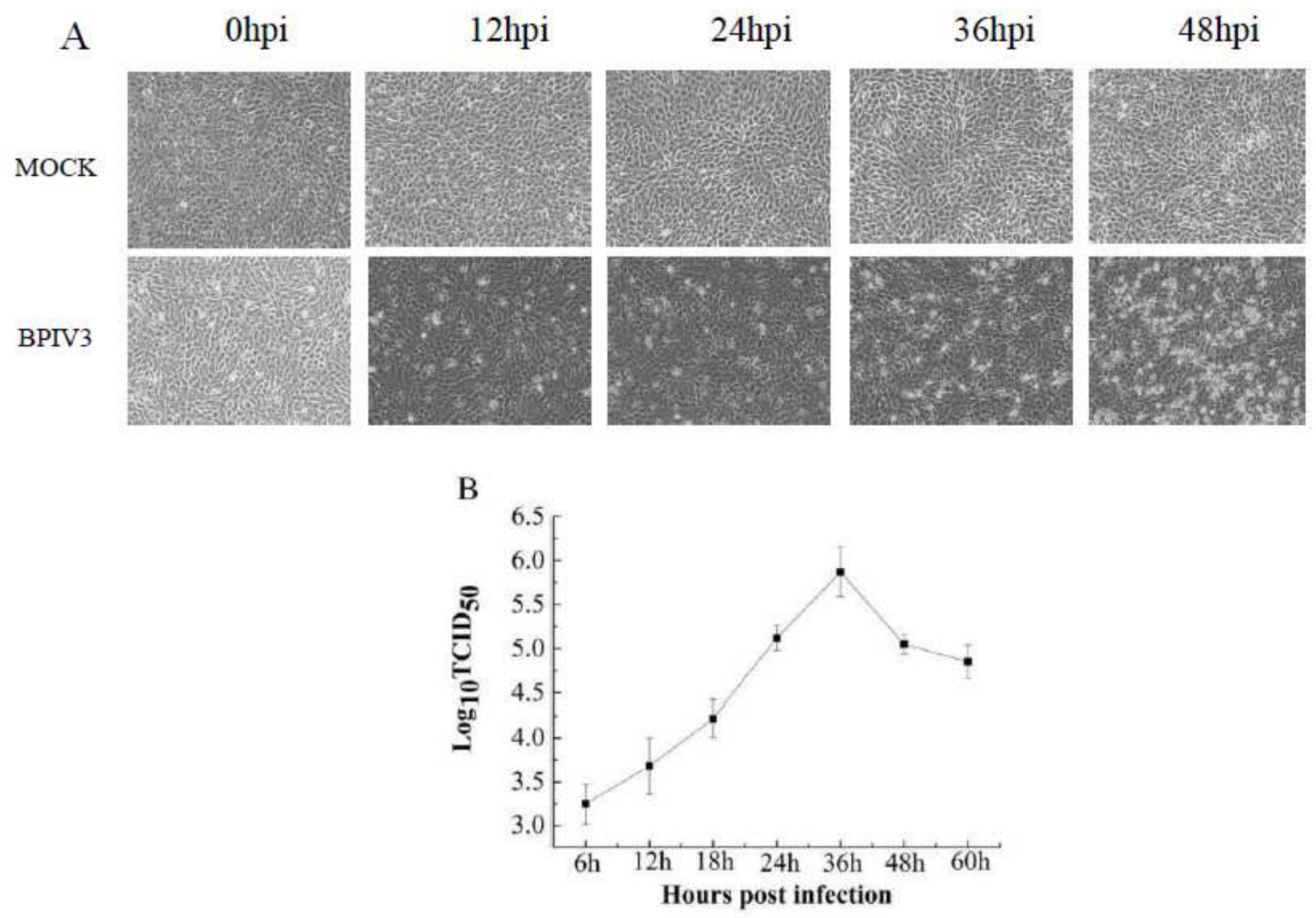

\section{Figure 1}

Virus infection. (A) Photomicrographs of MDBK cells infected with BPIV3 strain DQ at $\mathrm{MOI}=1$ or mockinfected at different times after infection (indicated at top). Images were taken at an original magnifification of 40x. (B) One-step growth curve of BPIV3 strain DQ in MDBK cells. 


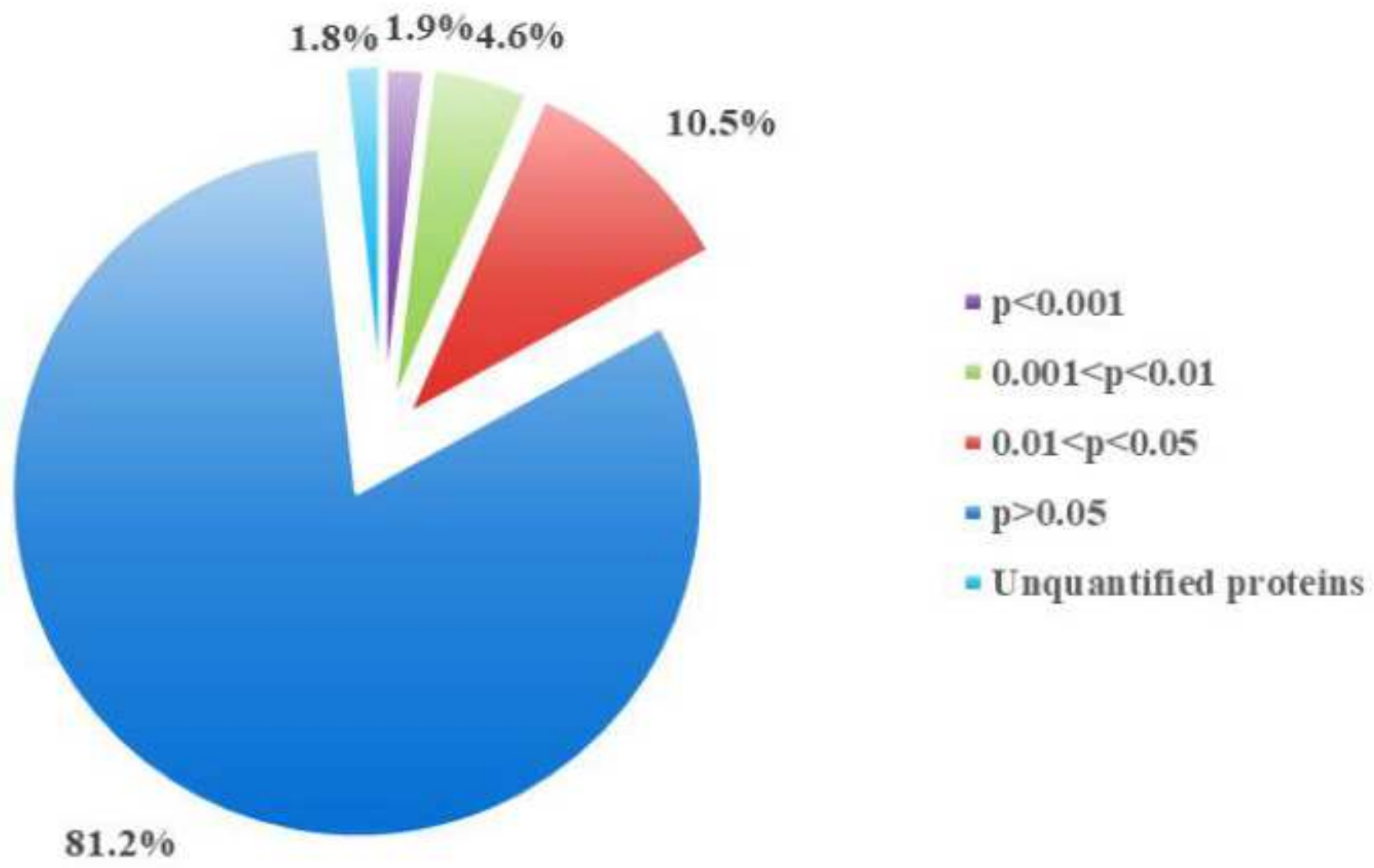

Figure 2

The quantitation and significance of the 2804 identified proteins from BPIV3-infected and mock-infected groups.

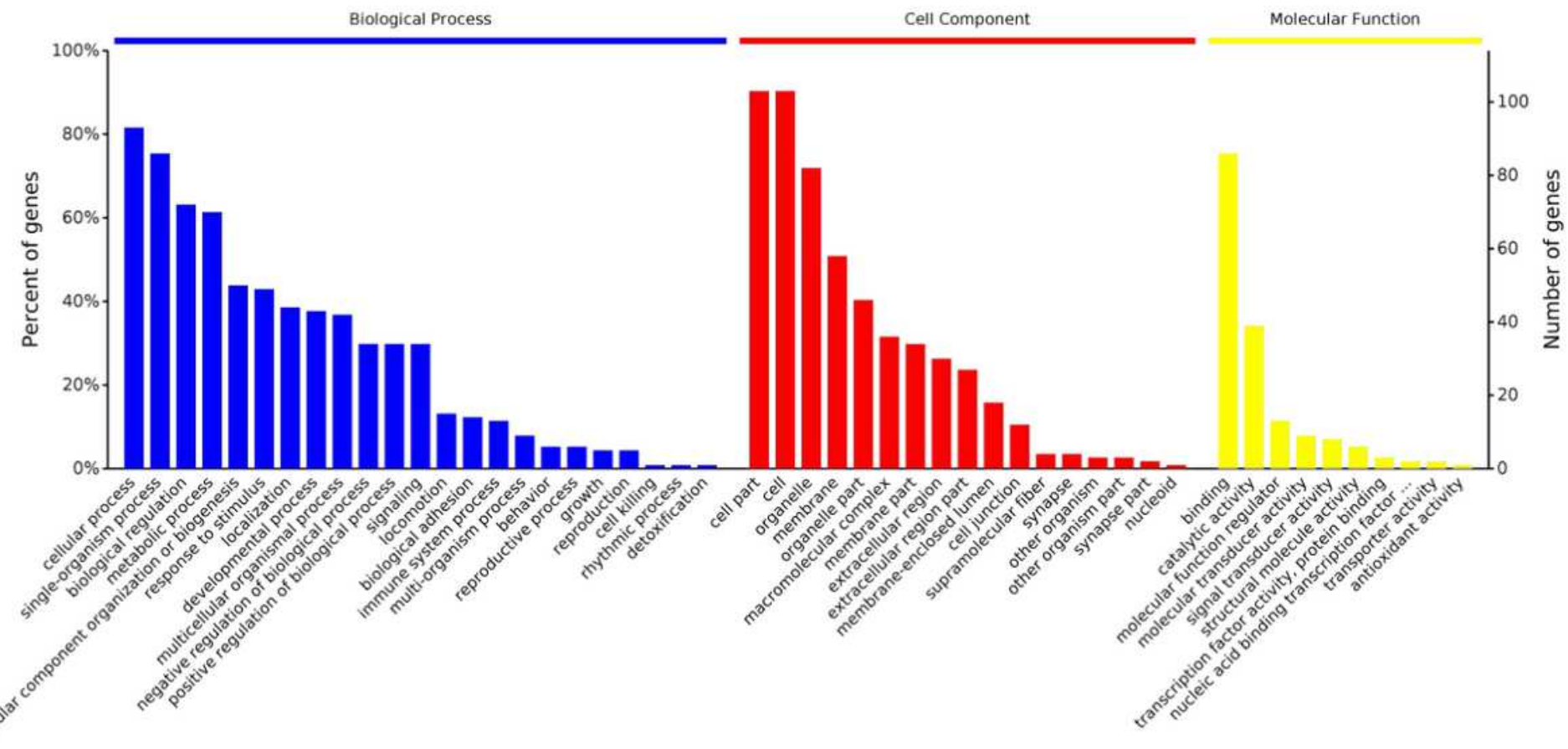

Figure 3 
Gene ontology (biological process) analysis of the DEPs in BPIV3 groups vs. the control groups. The right coordinate axis indicates the number of proteins for each GO annotation, the down coordinate axis indicates the GO annotations. Blue stripes indicates that biological processes categories of DEPs; red stripes indicates that categories of cell components; yellow stripes indicates that categories of the molecular functions.

\section{A II Down-regulated proteins in Up-regulated proteins}

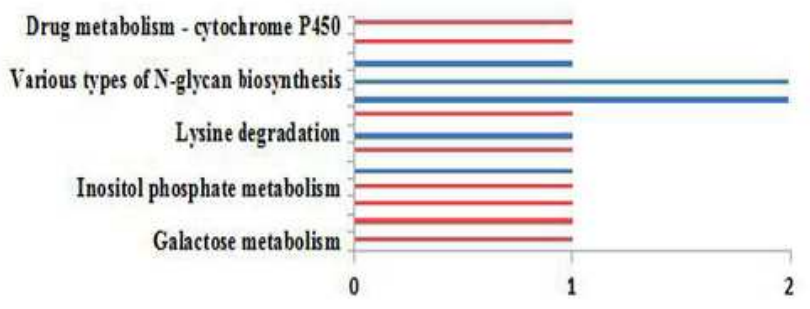

Number of proteins

C Down-regulated proteins $\|$ Up-regulated proteins

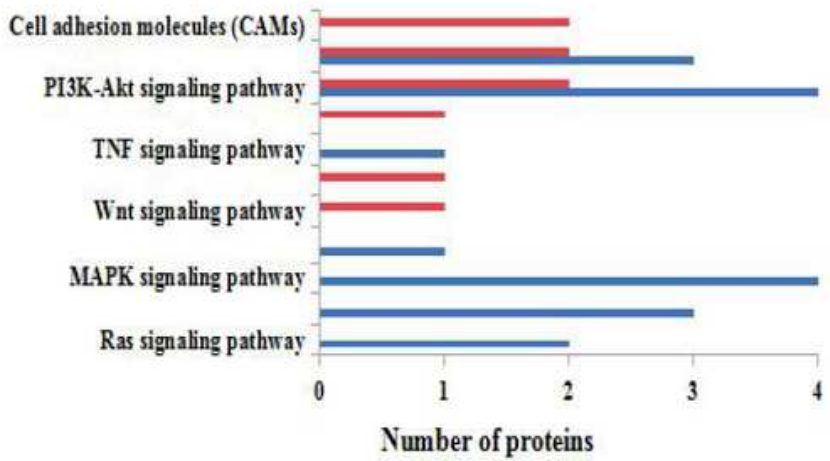

E $\quad$ Down-regulated proteins $\|$ Up-regulated proteins

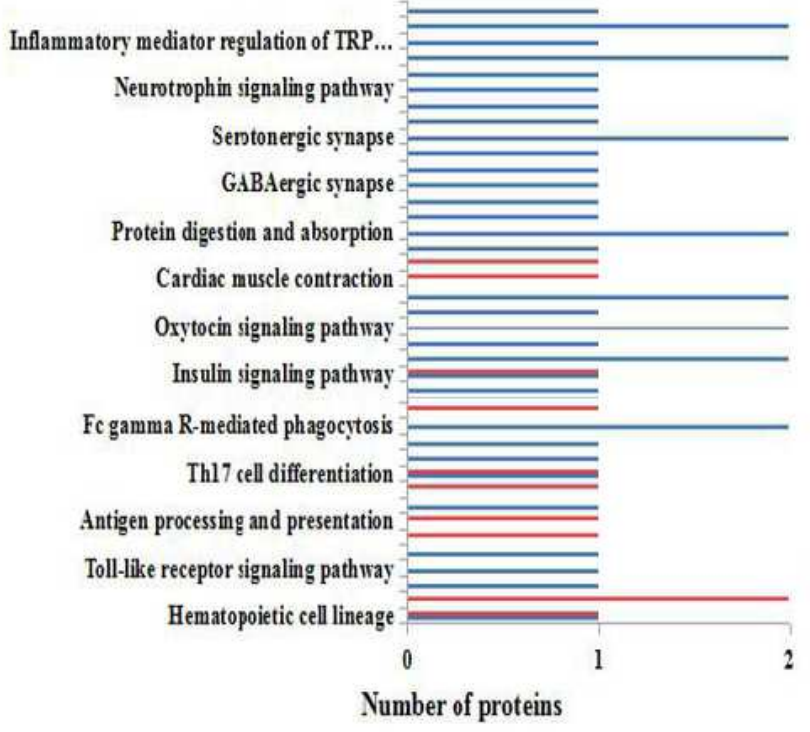

B Down-regulated proteins $\|$ Up-regulated proteins

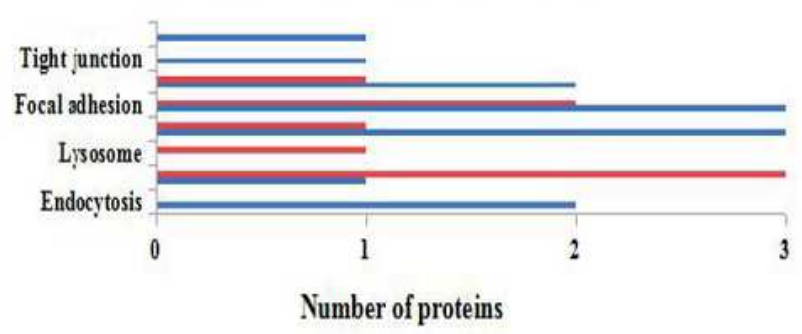

D Down-regulated proteins |n Up-regulated proteins

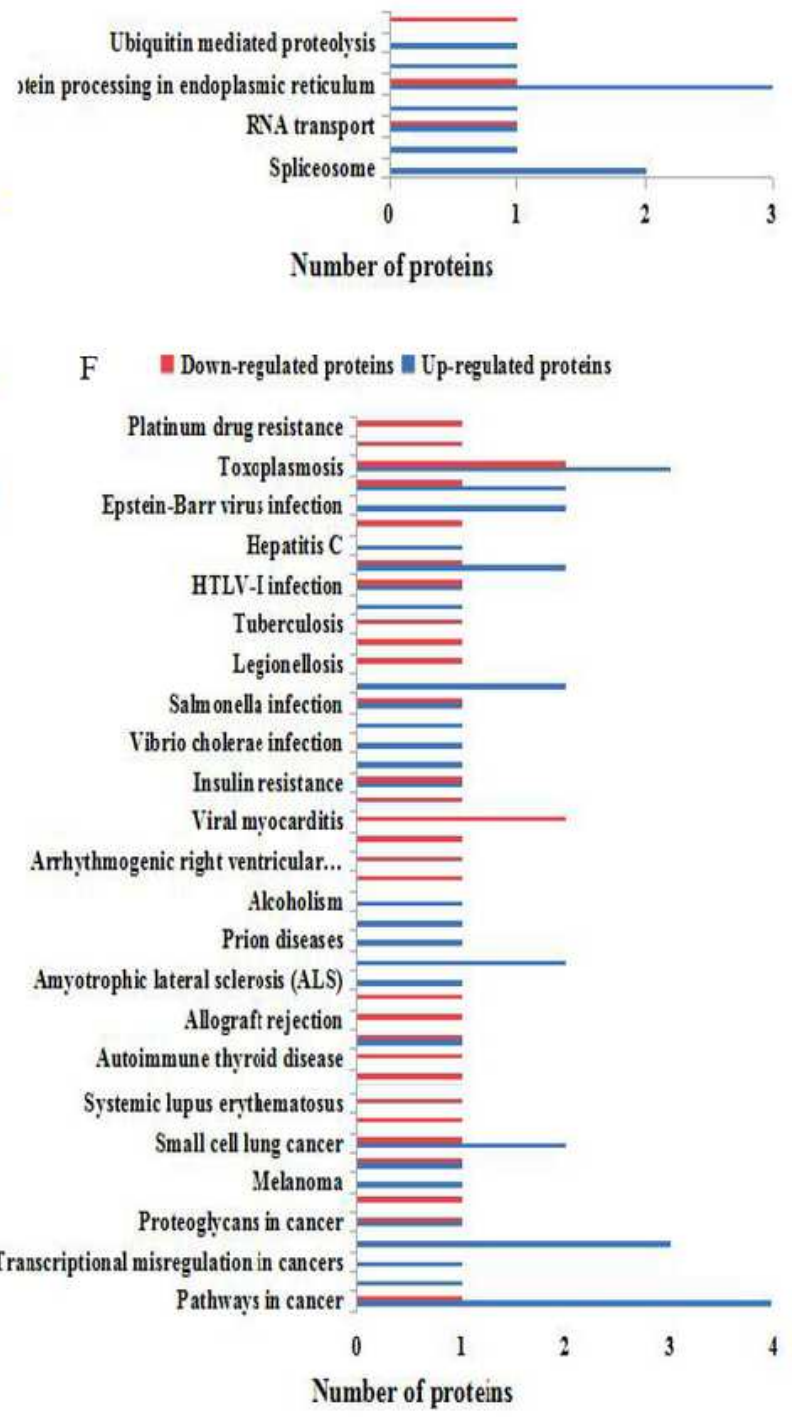


Analysis of the KEGG pathway of the differentially expressed proteins. (A) genetic information processing (B) Metabolism; (C) environmental information processing; (D) cellular processes; (E) organismal systems; (F) diseases.
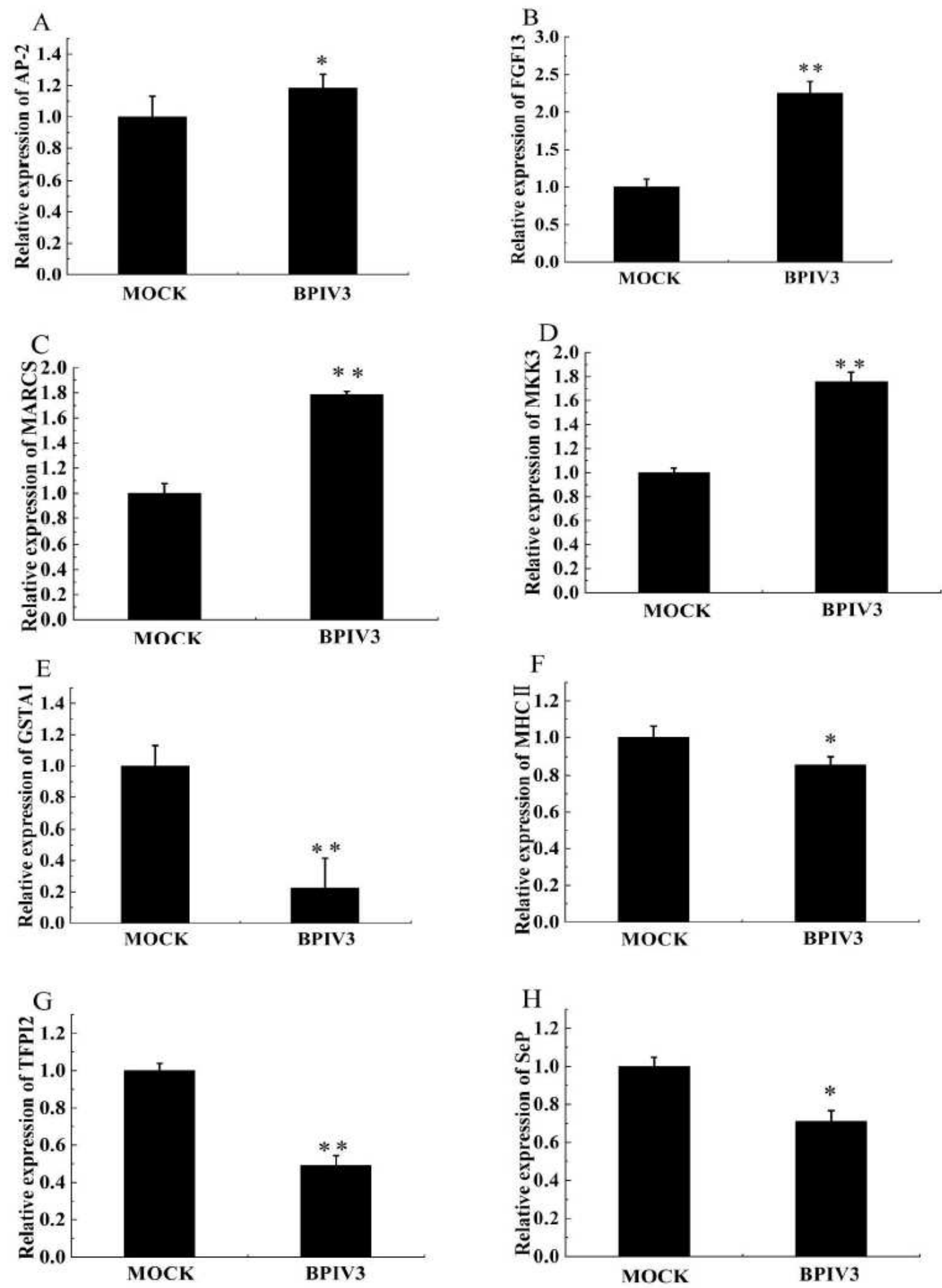

Figure 5

Real-time RT-PCR analysis of the DEPs in BPIV3-infected cells and controls. MDBK cells were infected with BPIV3 at MOI=1or mock-infected. The cells were collected at $24 \mathrm{hpi}$ for real-time RT-PCR to analyze 
the relative expression of 8 differential expression genes. (A).Relative expression of AP-2; (B) Relative expression of FGF13; (C) Relative expression of MARCS; (D) Relative expression of MKK3; (E) Relative expression of GSTA1; (F) Relative expression of MHCll; (G) Relative expression of TFPI2; (H) Relative expression of SepP.

A
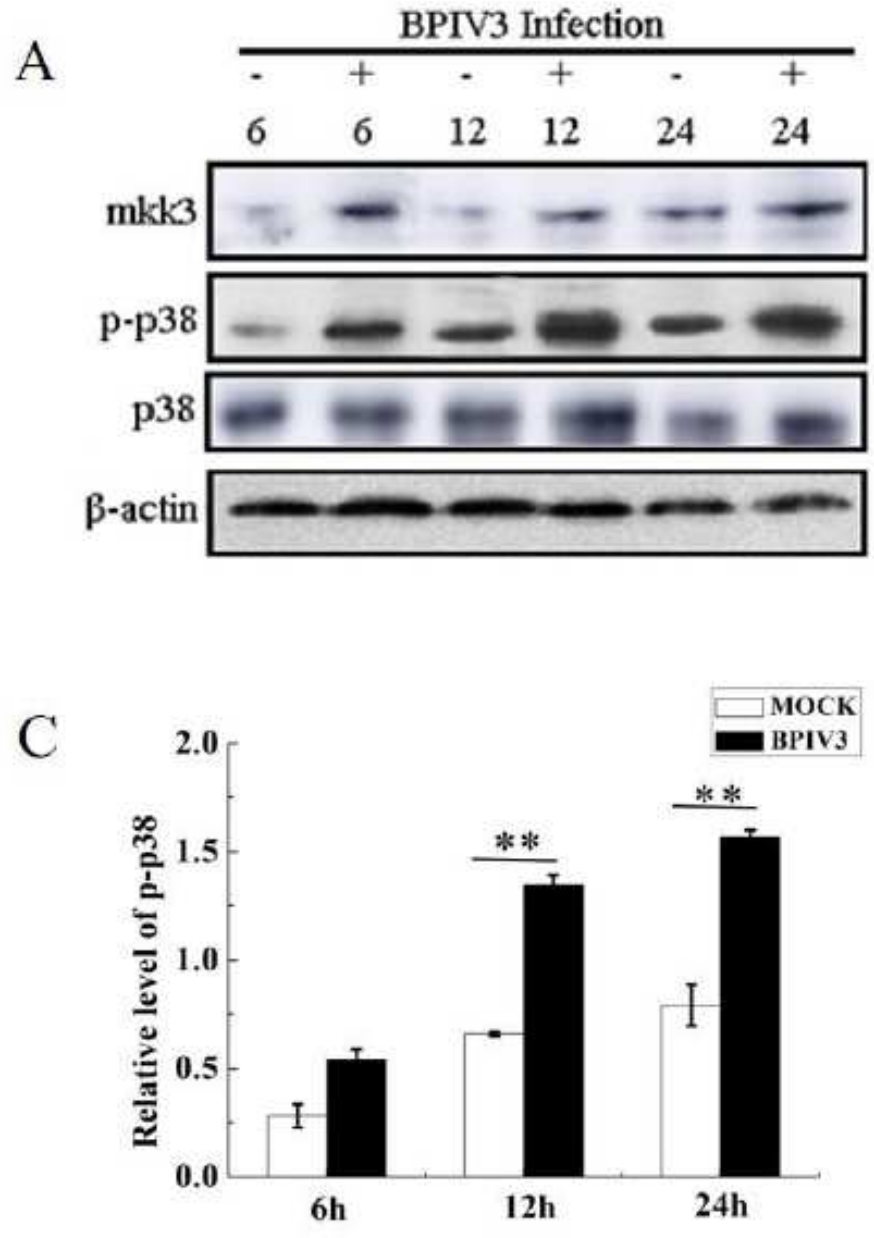

B

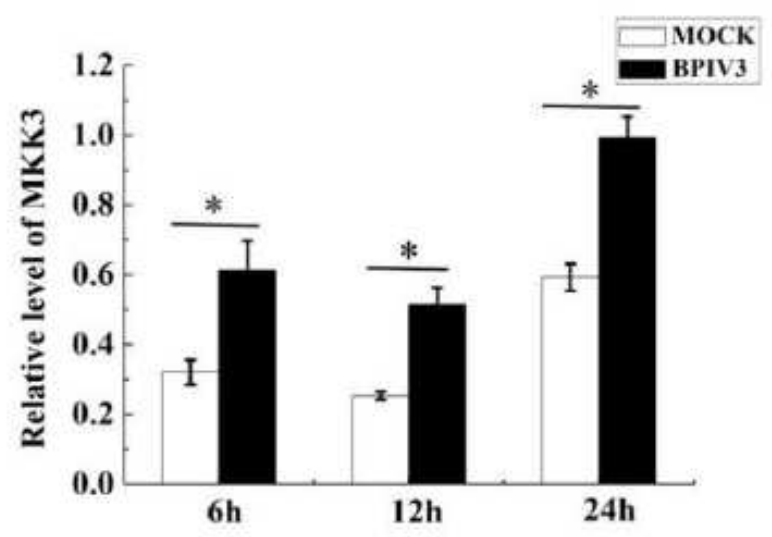

D

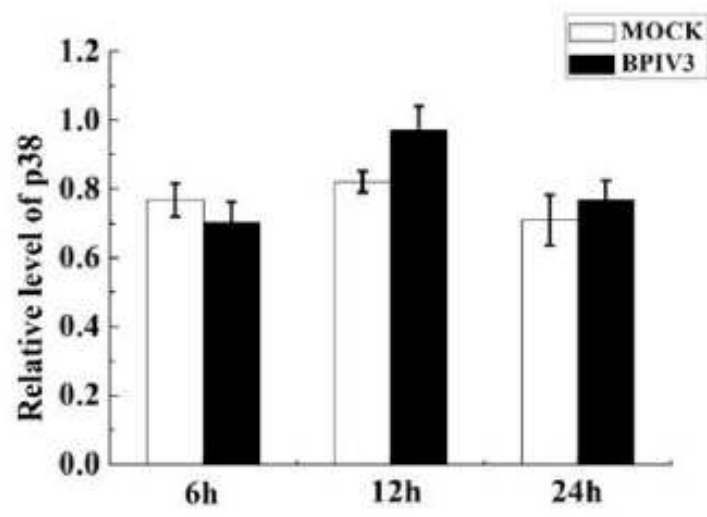

Figure 6

P38 MAPK pathway was activated by BPIV3 infection. (A) MDBK cells were mock-infected or infected with BPIV3 at multiplicity of infection (MOI) of 1 from 6 to 24 h, MKK3, p38 phosphorylation and total amount of p38 were analyzed in whole-cell lysates by Western blot with a specific mouse anti-phosphop38 (9216, CST, USA), rabbit anti-p38 (41666, CST, USA) and rabbit anti-MKK3 (5674, CST, USA) antibodies followed by second antibody. $\beta$-actin probed with specific monoclonal antibody was served as loading control. Densitometry scans were conducted using ImageJ software (NIH, USA). Densitometry of the phospho-p38 band normalized to p38 is presented as fold change \pm SEM compared with the mockinfected control defined as 1 . These data were from three independent experiments. Significant differences compared with mock-infected control are denoted by $*(P<0.05), * \star(P<0.01)$. The Same densitometry analysis and statistical analysis were performed in the following experiments. $(A)$ The protein expression in p38 MAPK pathway by Western blot; (B) Expression of MKK3; (C) Expression of pp38; (D) Expression of p38 

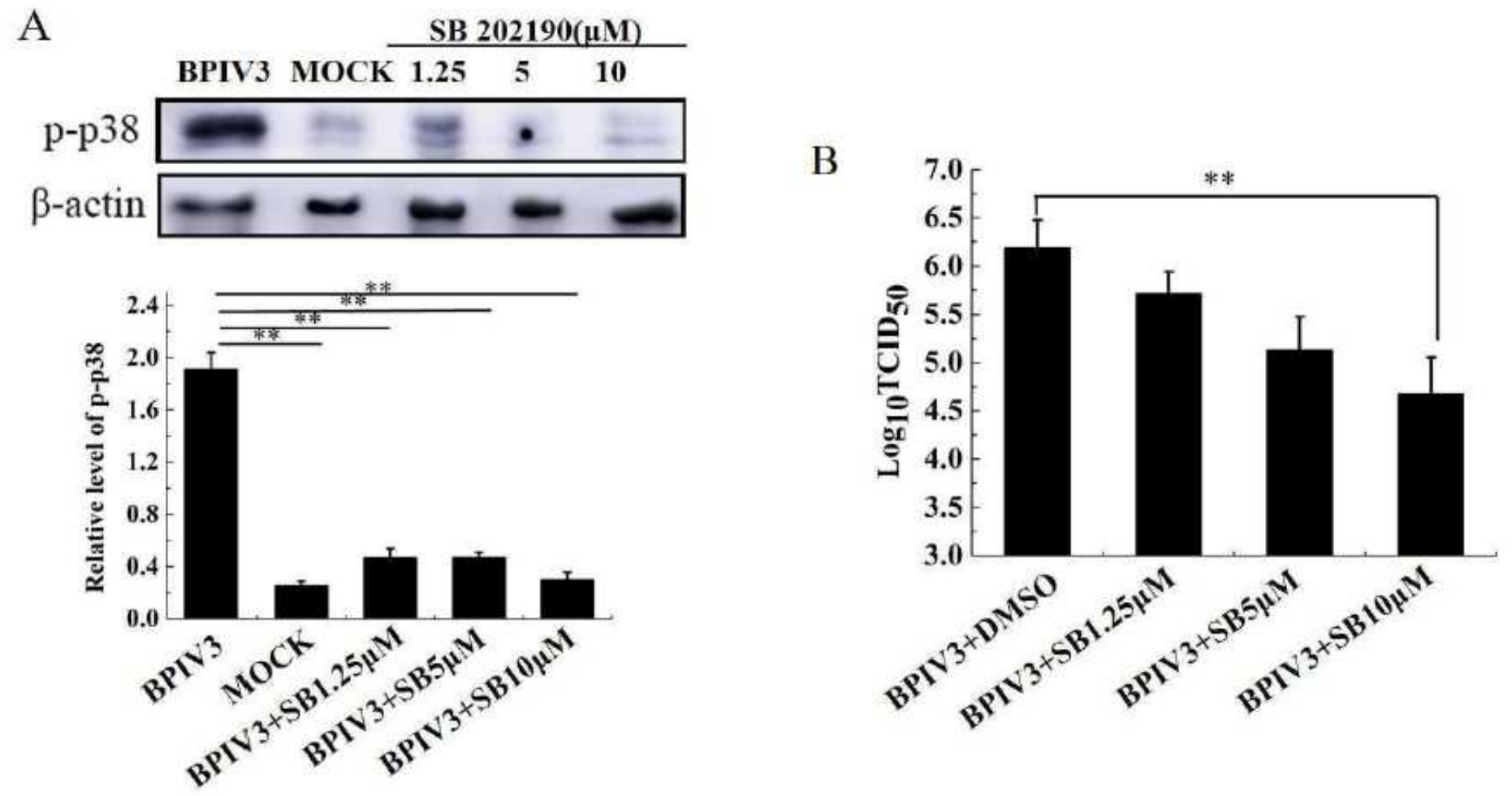

Figure 7

Inhibition of activation of the p38 pathway inhibits BPIV3 replication. MDBK cells were treated with SB202190 at 1.25, 5, and $10 \mathrm{M}$ concentrations. After $1 \mathrm{~h}, \mathrm{BPIV} 3$-infected cells were inoculated with $\mathrm{MOI}=1$. Cell samples were collected at $24 \mathrm{~h}$ after infection, and the following tests were performed: (1) Cell samples were collected $24 \mathrm{~h}$ after infection, lysed with cell lysate, and the expression of phospho-p38 and $\beta$-actin in the samples was detected by Western-blot. (A) SB202190 impact on p38MAPK phosphorylation; (B) The cell supernatant was collected $24 \mathrm{~h}$ after infection, and the titer of the virus was detected by TCID50 assay.SB202190 impact on Bpiv3 TCID50.** $(P<0.01)$ 